\title{
Sustainable utilization of bauxite residue (Red Mud) as a road material in pavements: A critical review
}

Jizhe Zhang, Zhanyong Yao, Kai Wang, Fei Wang, Hongguang Jiang, Ming Liang, Jincheng Wei, Gordon Airey

\section{Contents}

1. Introduction

2. Generation and management strategies of red mud

2.1 Red mud generation

2.2 Traditional management strategies of red mud

2.3 Sustainable management strategies for utilizing red mud

3. Characteristics and potential environment impacts of red mud

3.1 Chemical compositions of red mud

3.2 Physical properties of red mud

3.3 Environmental effect of red mud

4. Utilization of red mud in base courses

5. Utilization of red mud in asphalt mixtures

5.1 Red mud in asphalt mastic

5.2 Red mud in asphalt mixtures

6. Conclusions and recommendations

\begin{abstract}
Sustainable utilization of the bauxite residue (red mud) generated from alumina refining has recently increased due to increased environmental concerns because of its high alkalinity and problematic pollutants when placed in landfills. This paper attempts to review recent research findings of utilizing red mud as a road material in pavement structures, including road bases and asphalt mixtures. Previous laboratory investigations indicated that red mud is feasible to be used as a raw material in road bases with satisfactory unconfined compressive strength (UCS), frost resistance and durability performance, but their durability during the service life of the pavement is still unclear. The incorporation of red mud in asphalt mastics was found to be able to improve its stiffness, such as softening point, complex modulus and viscosity. In terms of asphalt mixtures, replacing limestone filler in mixtures by red mud resulted in some positive effects on mechanical behaviors, high bulk density and good rutting resistance. However, the moisture susceptibility and raveling resistance of asphalt mixtures became relatively worse because of the addition of red mud. Referring to this overview, it is necessary to qualify the long-term service performance of road base materials prepared with red mud by using laboratory accelerating evaluation or road trials. For asphalt mixtures prepared with red mud, how to improve durability, in particular moisture resistance, will be a future research focus. In addition, the influence of red mud on cracking resistance at low temperature, fatigue properties and long-term durability of asphalt mixtures is still needed to be further explored.
\end{abstract}

Keywords: Red mud; Pavements; Road base; Asphalt mixture; Asphalt mastic 


\section{Introduction}

The worldwide industrialization and urbanization have promoted a high demand of aluminum, which has in turn accelerated the emission of by-products during the extraction and refining processes of bauxite [1]. Red mud (Bauxite residue) is a type of industrial waste discharged by alkali treatment of bauxite in order to extract aluminum. Due to its high content of iron oxide, this type of solid waste appears red or brown and is commonly known as red mud. Generally, depending on the raw material quality and processes, generating one ton of alumina will discharge around 0.62.5 tons of red mud, and this results in a massive amount of red mud generated in the industry [2]. Because red mud has high alkalinity and potential environment pollution, it cannot be disposed directly and pumping into holding ponds is a commonly used approach [3][4][5]. Even if it is dry, the landfills used for disposal of red mud are still limited due to its considerable amount [6]. Up to now, the cumulative stock of red mud is around 600 million tons in the world, but the comprehensive utilization rate is less than $5 \%$ [7]. Therefore, with the promotion of environmental protection, it is highly desirable to minimize red mud waste disposal by adopting effective and efficient methods to utilize it as a secondary resource.

In the literature, enormous attempts have been made to find suitable approaches to realize the innocuous utilization of red mud. Because red mud contains a high amount of metallic oxides and alkalis, there are numerous research studies seeking to further recover alumina, soda, ferric and titanium oxide [8][9]. So far a main application of red mud is to reuse it for producing construction/building materials such as light weight aggregates [10], bricks [11], low density foamed products [12], and traditional ceramics [13]. In addition, red mud can also be widely used in the cement industry, where it can be considered as a raw material or additive for cement production and can act as a replacement of cement in concrete production [14][15]. Due to its alkalis and aluminates presence, as well as high alkalinity, the utilization of red mud to produce geo-polymer has also attracted attention in recent years [16][17]. The developed geo-polymer materials can be applied in different practical fields, such as paving blocks [18], road base materials [19], and phase change materials [20]. Because red mud is the mixture of oxides and hydroxides with fine particles, the purpose of using red mud as absorbents has been motivated, and several studies have reported utilizing red mud for adsorbing pollutants, such as phosphate [21], congo red [22], fluoride [23], nitrate [24], heavy metals [25][26], etc., from water or wastewater. Although there are several attempts to utilize red mud, the consumption of this solid waste is still relatively low.

In recent years, utilization of red mud has been extended to the field of pavements as a road material to replace natural materials used in road bases and asphalt mixtures. A brief overview of the literature reveals that the application of red mud in asphalt mixtures is limited due to a lack of experimental investigations in the laboratory. One research direction is to focus on the mechanical performance development of road base materials after adding red mud. The other one is to study the mechanical behavior of asphalt mixtures by using red mud as the replacement of mineral fillers. This review thus gives a synthetical overview of the development of red mud utilization in pavements during the past decades. First, characteristics of red mud including physical, chemical, as well as environmental impacts, were reviewed and its potential in road pavements was evaluated. Following this, utilizing red mud in road bases and asphalt mixtures were individually summarized by considering the achievements and shortcomings. Finally, conclusions and 
recommendations were presented and new potential research areas were presented.

\section{Generation and waste management strategies of red mud}

\subsection{Generation of alumina and bauxite residues}

Bauxite is one of the most important naturally occurring resources for producing aluminum, with $98 \%$ of aluminum estimated to be extracted from bauxite throughout the world [27]. Bauxite is a natural ore which normally composing aluminum hydroxide minerals such as gibbsite $\left(\mathrm{Al}(\mathrm{OH})_{3}\right)$, boehmite $(\gamma-\mathrm{AlO}(\mathrm{OH}))$, and diaspore $(\alpha-\mathrm{AlO}(\mathrm{OH}))$ [28]. In addition, bauxite contains other impurities, which include quartz $\left(\mathrm{SiO}_{2}\right)$, hematite $\left(\alpha-\mathrm{Fe}_{2} \mathrm{O}_{3}\right)$, rutile/anatase $\left(\mathrm{TiO}_{2}\right)$, kaolinite $\left(\mathrm{Al}_{2} \mathrm{Si}_{2} \mathrm{O}_{5}(\mathrm{OH})_{4}\right)$, and other minor minerals [29].

Because of the difference in terms of the mineral content of bauxite resources, there are different aluminum production methods including the Bayer process, Sintering process, and Combination Bayer-sintering process. The Bayer process developed by Karl Josef Bayer in 1888 is the most commonly used process for commercial aluminum production [2]. This method is suitable for refining bauxite ores with a high $\mathrm{Al}_{2} \mathrm{O}_{3} / \mathrm{SiO}_{2}$ ratio between 7-10 [30]. To produce aluminum by the Bayer process, the bauxite is first milled and then mixed with water, lime and caustic soda to digest the bauxite components at high temperature and pressure, as shown in Figure 1. It should be noted that the optimal processing conditions, which include the pressure, temperature and the caustic concentration, are significantly affected by the characteristic of bauxite resources. During the digestion stage, the useful minerals in bauxite (gibbsite, boehmite, and diaspore) are digested by the sodium hydroxide liquid and then the aluminum hydroxide $\left(\mathrm{Al}(\mathrm{OH})_{3}\right)$ is selectively precipitated, as shown in Equations 1 and 2. These two chemical equations increase their reactions with increasing temperature and caustic soda concentration [31].

Gibbsite:

$\mathrm{Al}_{2} \mathrm{O}_{3} \cdot 3 \mathrm{H}_{2} \mathrm{O}+2 \mathrm{OH}^{-} \rightarrow 2\left[\mathrm{Al}(\mathrm{OH})_{4}\right]^{-}$

Boehmite and diaspore:

$\mathrm{Al}_{2} \mathrm{O}_{3} \cdot \mathrm{H}_{2} \mathrm{O}+2 \mathrm{OH}^{-}+2 \mathrm{H}_{2} \mathrm{O} \rightarrow 2\left[\mathrm{Al}(\mathrm{OH})_{4}\right]^{-}$

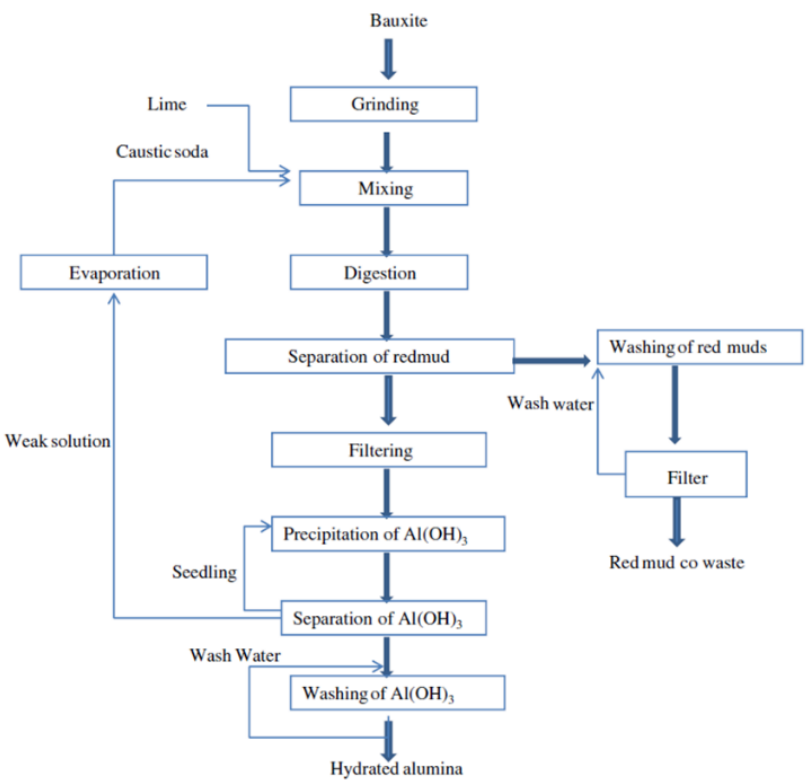

Figure 1. A schematic representation of the Bayer process [32]. 
The Sintering process is unique in China and Russia, which is used to deal with relatively low-grade bauxite ores with $\mathrm{Al}_{2} \mathrm{O}_{3} / \mathrm{SiO}_{2}$ ratios ranging between 3 and 6 [30]. To produce aluminum, bauxite was first sintered in rotary sintering kilns by adding limestone and soda ash at a temperature above $1200^{\circ} \mathrm{C}$ with sodium aluminate (soluble) and calcium silicate (insoluble) being generated, as shown in Equations 3 and 4. The detailed schematic process for the Sintering method is shown in Figure 2 .

$\mathrm{Na}_{2} \mathrm{CO}_{3}+\mathrm{Al}_{2} \mathrm{O}_{3} \rightarrow \mathrm{Na}_{2} \mathrm{O} \cdot \mathrm{Al}_{2} \mathrm{O}_{3}+\mathrm{CO}_{2} \uparrow$

$2 \mathrm{CaO}+\mathrm{SiO}_{2} \rightarrow 2 \mathrm{CaO} \cdot \mathrm{SiO}_{2}$

During the sintering process, ferric oxide is combined with soda ash to form sodium ferrite, as shown in Equation 5.

$\mathrm{Na}_{2} \mathrm{CO}_{3}+\mathrm{Fe}_{2} \mathrm{O}_{3} \rightarrow \mathrm{Na}_{2} \mathrm{O} \cdot \mathrm{Fe}_{2} \mathrm{O}_{3}+\mathrm{CO}_{2} \uparrow$

The sintered bauxite clinker is then dissolved by water and the soluble $\mathrm{Na}_{2} \mathrm{O} \cdot \mathrm{Al}_{2} \mathrm{O}_{3}$ enters the solution. The sodium aluminate is finally treated by carbon dioxide to obtain aluminum hydroxide. The retained insoluble iron oxide hydrate and calcium orthosilicate are discharged as the bauxite residue (red mud) [33][34]. It should be mentioned that the Sintering process consumes significantly higher energy than that of the Bayer process and the combined Bayer-sintering process [7].

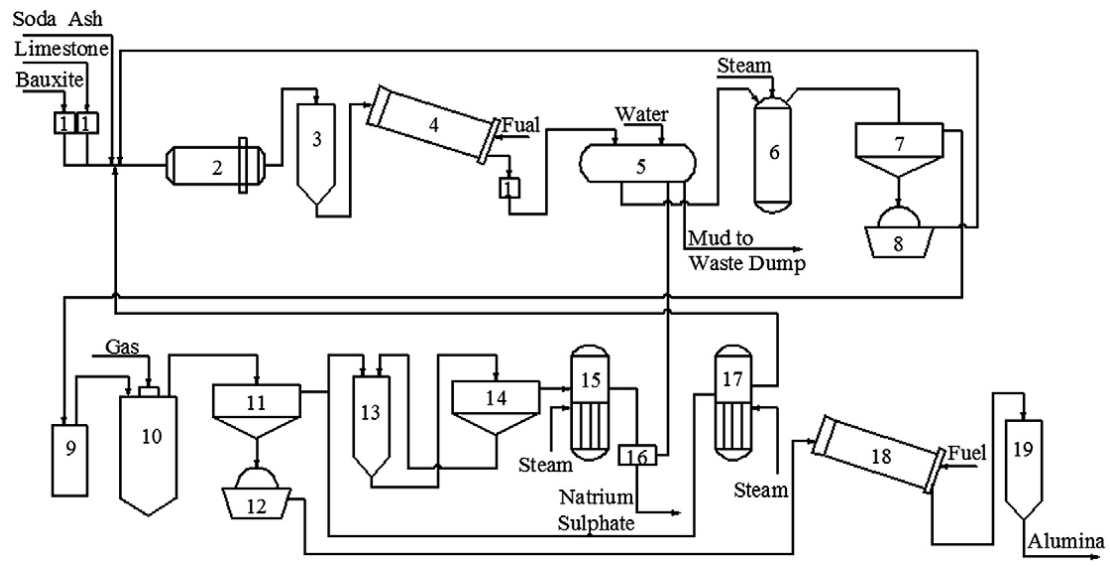

Figure 2. A schematic representation of the Sintering process. 1-crushing; 2-wet grinding; 3correction of pulp; 4-sintering; 5-leaching; 6-first desilication; 7-thickening; 8-filtration; 9-second desilicatin; 10-carbonization; 11-thickening; 12-filtration; 13-precipitation; 14-thickening; 15-

evaporation; 16-filtration; 17-evaporation; 18-calcination; 19-silo for alumina [2].

The Combination Bayer-sintering process is a developed approach based on the standard Bayer process with the view of resolving the problem of high silica content in some bauxite ores. During this process, as shown in Figure 3, the high-silica bauxite was first subjected to a traditional Bayer caustic leach process. The generated bauxite residue with sodium aluminum silicates was then subjected to the sintered process, and followed by a leaching process with water to reclaim alumina and soda [35][36]. 


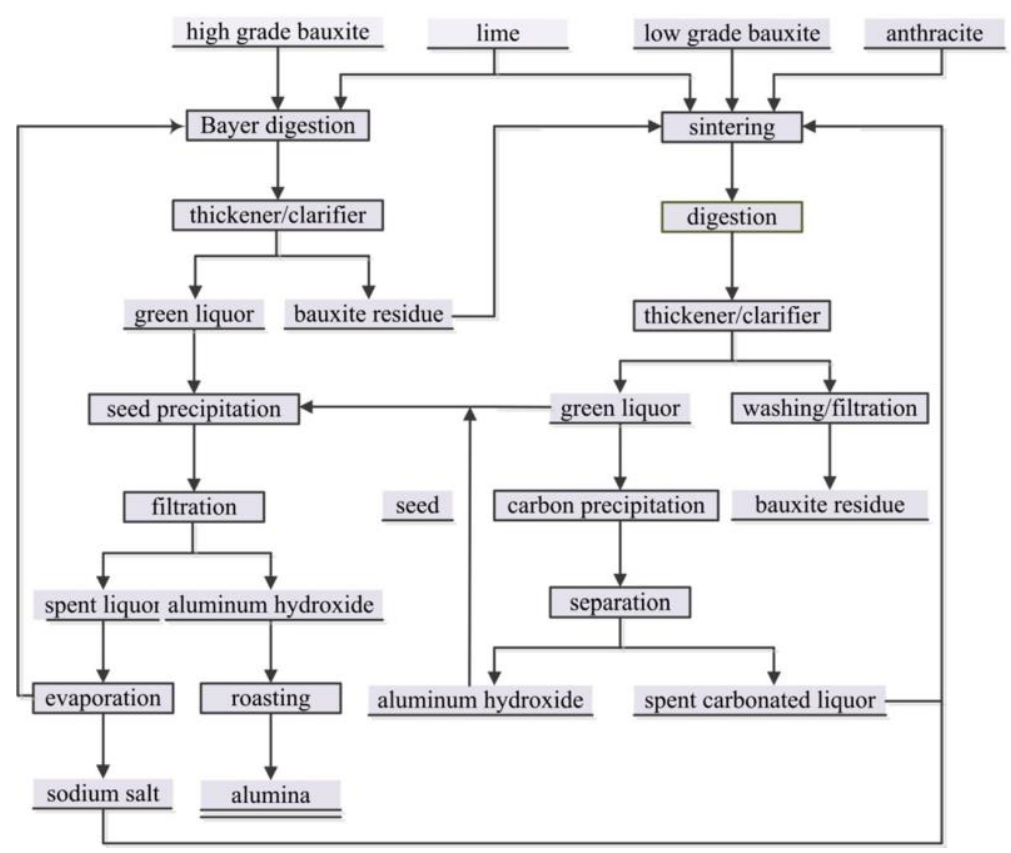

Figure 3. A schematic representation of the Combination Bayer-sintering process [37]

Depending on the bauxite grade and the extraction process, there are around 0.6-2.5 tons of red mud generated when producing 1 ton of alumina [38]. It has been estimated that the annual red mud emission in 2018 was over 160 tons worldwide with about 105 million tons generated in China [39].

\subsection{Traditional waste management strategy of red mud}

The normally adopted waste management method of the processed red mud is by landfilling. However, with the increasing awareness of environmental protection and land conservation, how to dispose of bauxite residue properly is a great challenge to the aluminum industry throughout the world. Because of this, considerable research has been conducted to change present disposal waste management approaches [40][41]. Normally, there are three main technologies for bauxite residue disposal to landfills, including wet processing, dry processing and semi-dry processing [42]. In the wet processing, the bauxite residue is first washed in a thickener to promote the sedimentation of the solids and obtain residue slurry with the solids content ranging between $15 \%$ $30 \%$. The residue slurry is then pumped into a storage yard created by dams, tailing ponds and other earthworks to allow the solids to deposit and the supernatant liquid in the storage yard is then collected as recovered caustic soda [43]. As the dilute residue slurry has a high alkalinity with a $\mathrm{pH}>12$, its disposal after wet processing has a risk of leaking caustic and alkaline liquid into subsoil water and triggering environmental hazards to the surrounding area/communities [44].

As landfills are now becoming scarce and limited, the dry stacking method has been adopted by many plants because of its advantages such as reduced space occupation of the bauxite residue and less leakage potential [7][45]. In this process, the bauxite residue is pre-thickening to obtain residue slurry with a solid content over $50 \%$ and then deposited in layers with a thickness of 0.4 $0.7 \mathrm{~m}$. The high solid content of the residue slurry can be realized through filtration by using drum filters or a plate and frame filter press, as shown in Figure 4. As the top layer of slurry is dry, bulldozers are used to turn up the bottom layer in order to accelerate the drying process and reduce dust emissions. Then, consecutive residue slurry is layered on top to allow the increase in the spatial storage yard, which subsequently reduces the landfill occupied [46]. 


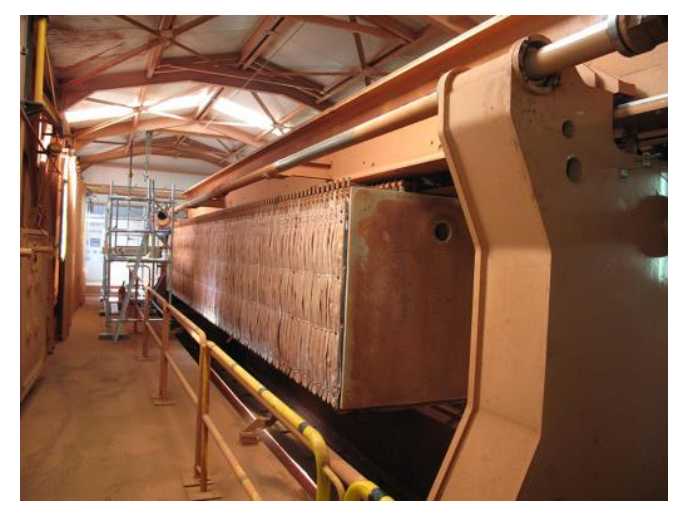

Figure 4. Plate and frame filter press, Gardanne, France [44].

The semi-dry processing is the result of a co-disposal of bauxite residue slurry generated from the Bayer process and the sintering process. The residue from the sintering process normally has a low permeability coefficient and a high shear yield strength because of its hydration and hardening ability. So, the dried residue from the sintering process can be applied to construct a dam as a direct replacement of clay. Meanwhile, the residue slurry from the Bayer process can be pumped into the dam directly without dewatering [47].

Among these three disposal processes to landfills, some efforts have been done to partially neutralize high alkalinity to minimize its environmental impacts, including seawater neutralization in plants close to the sea, carbonation using waste carbon dioxide obtained during production, as well as accelerated carbonation using intensive farming methods.

Up to now, collaborative attempts are still ongoing to seek reasonable solutions for bauxite residue disposal, such as improving storage, monitoring and safety standards to reduce environment impacts, developing remediation techniques to improve the reclamation potential of storage yard, and promoting reuse approaches to reduce the volume of stocked bauxite residue [48][49]. Even though such measures are being developed, red mud still occupies considerably landfills and sustainable waste management strategies are needed to use red mud as a secondary resource material.

\subsection{Sustainable management strategies for utilizing red mud}

In the recent two decades, alumina oxide production has experienced a rapid growth all over the world, as shown in Figure 5. The annual alumina oxide output increased from 52.583 million tons in 2000 to 125.999 million tons in 2017, while the annual emission of red mud reached to over 70 million tons [2]. Researchers have been thus working on developing sustainable and economical approaches for utilizing red mud. Table 1 summarizes possible techniques adopted for utilizing red mud in a variety of applications. It can be seen that there are numerous potential approaches for utilizing red mud with relatively established techniques. However, with respect to commercial/industrial implementation, the barriers for red mud utilization should not be neglected. In addition, the materials that red mud would be replacing are very common and easy to get. Because of this, any negative factor or minor impediment features may affect the largescale application of red mud. 


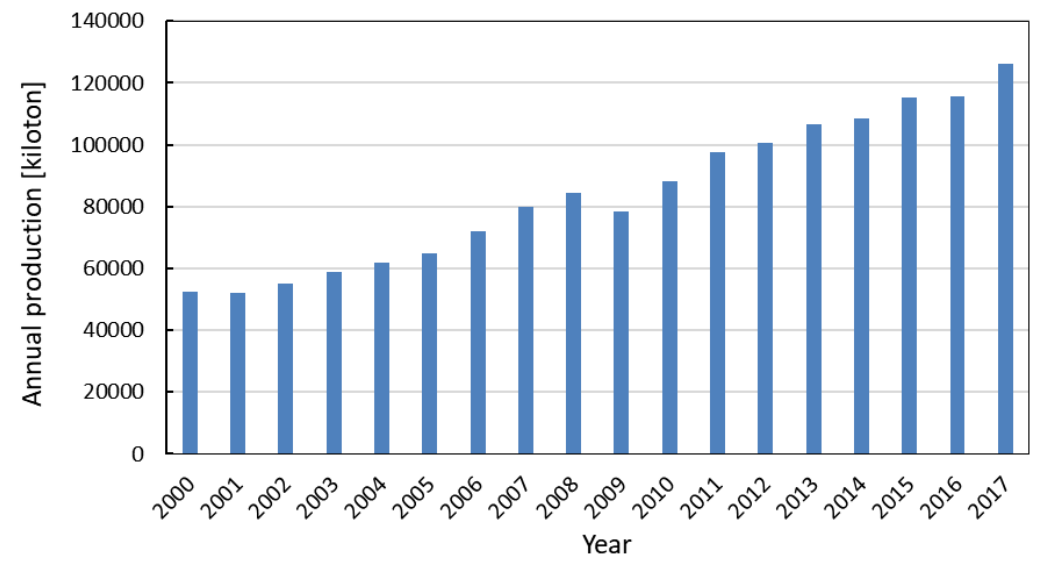

Figure 5. Annual aluminum oxide production throughout the world

Table 1. Summarized approaches for utilizing red mud in literature

\begin{tabular}{|c|c|c|c|}
\hline Categories & $\begin{array}{l}\text { Final products } \\
\text { or detailed } \\
\text { utilization }\end{array}$ & Practicality and Techniques & References \\
\hline \multirow{5}{*}{$\begin{array}{l}\text { Recovery of } \\
\text { valuable } \\
\text { elements }\end{array}$} & Sodium & $\begin{array}{l}\text { Mixed red mud with hydrated lime and treated in } \\
\text { hydrothermal process; Reduce the red mud } \\
\text { alkalinity; Solid residue could be used to produce } \\
\text { cement }\end{array}$ & [50] \\
\hline & Aluminum & $\begin{array}{l}10 \%-12 \% \text { sodium ferrite dosage; } 1.0-1.2 \mathrm{M} \text { ration of } \\
\text { calcium oxide to ferrite dosage; } 1000-1050{ }^{\circ} \mathrm{C} \\
\text { sintering temperature with } 30-40 \mathrm{~min}\end{array}$ & [51] \\
\hline & Iron & $\begin{array}{l}\text { Iron recovered through a reductive sintering- } \\
\text { magnetic separation-digesting process. } \mathrm{NaOH} \\
\text { solution with } 3 \% \text { concentration was used in the } \\
\text { digest process. }\end{array}$ & [52] \\
\hline & $\mathrm{Sc}_{2} \mathrm{O}_{3}, \mathrm{TiO}_{2}$ & $\begin{array}{l}\text { The } \mathrm{Sc}_{2} \mathrm{O}_{3} \text { was leached by the } \mathrm{HCl} \text { solution, while the } \\
\mathrm{TiO}_{2} \text { was leached by } \mathrm{H}_{2} \mathrm{SO}_{4} \text { solution. Finally } \\
\text { recovered by concentrating, hydrolyzing, washing } \\
\text { and calcination. }\end{array}$ & [53] \\
\hline & Scandium & $\begin{array}{l}\text { Extracted from red mud by activated carbon is } \\
\text { modified by tri-butyl phosphate (TBP). Not } \\
\text { economic. }\end{array}$ & [51] \\
\hline \multirow{3}{*}{$\begin{array}{l}\text { Environmental } \\
\text { applications }\end{array}$} & $\begin{array}{l}\text { Water } \\
\text { purification }\end{array}$ & $\begin{array}{l}\text { Because of its high specific adsorption area, red } \\
\text { mud can remove metal ions, cadmium ions and } \\
\text { arsenate from water. }\end{array}$ & {$[54][55][56]$} \\
\hline & Desulfurizer & $\begin{array}{l}\text { Absorbent } \mathrm{SO}_{2} \text { from acid waste gases using Bayer } \\
\text { bauxite residue because of its high alkali, large } \\
\text { absorption capacity and simple production process. }\end{array}$ & [57] \\
\hline & $\begin{array}{l}\text { Soil } \\
\text { remediation }\end{array}$ & $\begin{array}{l}\text { Using bauxite residue as additives to stabilize } \\
\text { polluted soil for minimizing the leaching of heavy } \\
\text { metals }\end{array}$ & [58] \\
\hline \multirow{3}{*}{$\begin{array}{l}\text { Construction } \\
\text { materials }\end{array}$} & Cement & $\begin{array}{l}\text { With high content of } \beta-2 \mathrm{CaO} \cdot \mathrm{SiO}_{2} \text {, red mud } \\
\text { can be incorporated as the raw meal to produce } \\
\text { Portland cement clinker at high temperature. }\end{array}$ & [59] \\
\hline & $\begin{array}{l}\text { Glass- } \\
\text { ceramics }\end{array}$ & $\begin{array}{l}\text { Sintering red mud contains suitable chemical } \\
\text { components }\left(\mathrm{CaO}, \mathrm{Al}_{2} \mathrm{O}_{3}, \mathrm{SiO}_{2}\right) \text { for producing glass- } \\
\text { ceramics; } \mathrm{CaO}-\mathrm{SiO}_{2}-\mathrm{Al}_{2} \mathrm{O}_{3} \text { glass-ceramic has been } \\
\text { made from red mud and fly ash. }\end{array}$ & [60] \\
\hline & $\begin{array}{l}\text { Fired building } \\
\text { materials }\end{array}$ & $\begin{array}{l}\text { Producing fired bricks with sintering temperature of } \\
1000{ }^{\circ} \mathrm{C} \text { and a holding time of } 120 \mathrm{~min} \text {; Using red } \\
\text { mud and barium carbonate to produce acid proof } \\
\text { fracturing proppants through sintering process and } \\
\text { the formation of monoclinic celsian }\left(\mathrm{BaAl}_{2} \mathrm{Si}_{2} \mathrm{O}_{8}\right) \\
\text { reduced the acid solubility. }\end{array}$ & [61][62] \\
\hline
\end{tabular}




\begin{tabular}{|l|l|l|l|}
\hline & $\begin{array}{l}\text { Non-fired } \\
\text { building } \\
\text { materials }\end{array}$ & $\begin{array}{l}\text { Producing composite baking-free brick with cement } \\
\text { and lime-fly ash depending on the combined } \\
\text { solidifying performance and reached the 1st-grade } \\
\text { of Chinese standard for the brick. }\end{array}$ & [63] \\
\hline
\end{tabular}

\section{Characteristics and potential environmental impacts of red mud}

\subsection{Chemical composition of red mud}

In order to make a reasonable use of the bauxite residue, it is of great important to obtain knowledge of its chemical and mineralogical composition so as to understand its unique physicochemical behavior for utilization [64][65]. The types and concentrations of chemical components in the bauxite residue vary widely based on the characteristics of the bauxite ore and the aluminum production process [66][67]. Regardless of extraction process, the dominant chemical oxide components in the bauxite residue are $\mathrm{Al}_{2} \mathrm{O}_{3}, \mathrm{Fe}_{2} \mathrm{O}_{3}, \mathrm{SiO}_{2}, \mathrm{TiO}_{2}, \mathrm{Na}_{2} \mathrm{O}$ and $\mathrm{CaO}$, with small quantities of $\mathrm{Ce}, \mathrm{Cl}, \mathrm{Cr}, \mathrm{K}, \mathrm{Mg}, \mathrm{Mn}, \mathrm{Nb}, \mathrm{P}, \mathrm{S}, \mathrm{Sr}, \mathrm{Th}, \mathrm{Y}, \mathrm{Zn}, \mathrm{Zr}$, and others [68]. Table 2 shows the main chemical oxide compositions of the bauxite residue generated from different alumina plants worldwide. As shown in this table, the concentrations of these six main components are $\mathrm{Al}_{2} \mathrm{O}_{3}(8-22 \%), \mathrm{Fe}_{2} \mathrm{O}_{3}(5-$ $46 \%), \mathrm{SiO}_{2}(5-25 \%), \mathrm{TiO}_{2}(2.5-17 \%), \mathrm{Na}_{2} \mathrm{O}(3-12 \%)$ and $\mathrm{CaO}(1-45 \%)$. It should be noticed that the residues produced from the sintering or combined Bayer-sintering process exhibit higher $\mathrm{CaO}$ (around $40 \%$ ) content than that from the Bayer process (less than 20\%). The higher $\mathrm{CaO}$ content endows the residue more cementitious behavior that has the potential to be a supplementary cementitious material [7].

Table 2. Chemical compositions of bauxite residue generated from different aluminum plants worldwide [7][43][59][69][70][71][72][73][74][75]

\begin{tabular}{|c|c|c|c|c|c|c|c|c|c|}
\hline \multirow[t]{2}{*}{ Country } & \multirow[t]{2}{*}{ Plant } & \multirow[t]{2}{*}{ Extraction process } & \multicolumn{6}{|c|}{ Major composition (wt.\%) } & \multirow[t]{2}{*}{ Reference } \\
\hline & & & $\mathrm{Al}_{2} \mathrm{O}_{3}$ & $\mathrm{Fe}_{2} \mathrm{O}_{3}$ & $\mathrm{SiO}_{2}$ & $\mathrm{TiO}_{2}$ & $\mathrm{Na}_{2} \mathrm{O}$ & $\mathrm{CaO}$ & \\
\hline China & Shanxi & Bayer-sintering & 10.05 & 6.75 & 22.2 & 2.55 & 3.00 & 42.25 & (Liu et al., 2014) \\
\hline China & Pingguo Alumina Co. LTD & Bayer & 18.49 & 31.26 & 8.35 & 6.18 & 3.23 & 18.05 & (Rao., 2010) \\
\hline China & Shandong alumina Co.LTD & Sintering & 8.03 & 17.54 & 18.19 & 4.81 & 3.21 & 44.64 & (Zhang et al., 2018) \\
\hline China & Shandong alumina Co.LTD & Bayer & 25.11 & 36.43 & 16.93 & 6.02 & 12.27 & 1.54 & (Zhang et al., 2018) \\
\hline China & Zhengzhou Alumina Co. LTD & Bayer-sintering & 7.60 & 8.20 & 20.40 & 7.30 & 3.00 & 44.70 & (Jiang et al., 2007) \\
\hline China & Shanxi Alumina Co. LTD & Bayer-sintering & 9.18 & 6.66 & 18.10 & 6.72 & 4.00 & 38.09 & (Nan et al., 2009) \\
\hline Spain & San Ciprián & Bayer & 19.8 & 39.23 & 8.77 & 10.09 & 5.02 & 4.54 & (Pérez-Villarejo et al., 2012) \\
\hline Brazil & Alunorte company & - & 19.0 & 38.0 & 19.9 & 3.83 & 8.58 & 0.87 & (Hildebrando et al., 2013) \\
\hline India & Bharat Aluminum Co. Ltd. & Bayer & 22.36 & 34.27 & 8.31 & 17.13 & 6.12 & 1.73 & (Samal et al., 2015) \\
\hline UK & ALCAN Chemicals plant & - & 20 & 46 & 5 & 6 & 8 & 1 & (Srikanth et al., 2005) \\
\hline Grece & Aluminum de Grece & - & 19.95 & 40.8 & 6.80 & 5.80 & 2.70 & 12.60 & (Tsakiridis et al., 2004) \\
\hline
\end{tabular}

Because of their different chemical oxide components, the mineralogical of the bauxite residue is even more complicated. It has been reported that there are numerus mineral compositions in the bauxite residue, including calcite $\left(\mathrm{CaCO}_{3}\right)$, diaspore $\mathrm{AlO}(\mathrm{OH})$, calcium aluminium hydrate (x.CaO.yAl $\left.{ }_{2} \mathrm{O}_{3} . \mathrm{zH}_{2} \mathrm{O}\right)$, quartz $\left(\mathrm{SiO}_{2}\right)$, hematite $\left(\mathrm{Fe}_{2} \mathrm{O}_{3}\right)$, gibbsite $\mathrm{Al}(\mathrm{OH})_{3}$, boehmite $\mathrm{AlO}(\mathrm{OH})$, rutile $\left(\mathrm{TiO}_{2}\right)$, anatase $\left(\mathrm{TiO}_{2}\right), \mathrm{CaTiO}_{3}, \mathrm{Na}_{2} \mathrm{TiO}_{3}$, kaolinite $\mathrm{Al}_{2} \mathrm{O}_{3} \cdot 2 \mathrm{SiO}_{2} \cdot 2 \mathrm{H}_{2} \mathrm{O}$, sodalites, aluminium silicates, cancrinite $\left(\mathrm{NaAlSiO}_{4}\right) 6 \mathrm{CaCO}_{3}$, hydroxycancrinite $\left(\mathrm{NaAlSiO}_{4}\right) 6 . \mathrm{NaOH} . \mathrm{H} 2 \mathrm{O}$, chantalite $\mathrm{CaO} . \mathrm{Al}_{2} \mathrm{O}_{3} \cdot \mathrm{SiO}_{2} \cdot 2 \mathrm{H}_{2} \mathrm{O}$ and hydrogarnet $\mathrm{Ca}_{3} \mathrm{Al}_{2}\left(\mathrm{SiO}_{4}\right) \mathrm{n}(\mathrm{OH})_{12-4 \mathrm{n}}$ [76]. By comparing different 
production processes, the red mud obtained from the sintering process contains more Calcite $\left(\mathrm{CaCO}_{3}\right)$, Dicalcium Silicate $\left(\mathrm{Ca}_{2} \mathrm{SiO}_{4}\right)$ and Perovskite $\left(\mathrm{CaTiO}_{3}\right)$, while those from the Bayer process contains more Hematite $\left(\mathrm{Fe}_{2} \mathrm{O}_{3}\right)$, gibbsite-Al $(\mathrm{OH})_{3}$ and goethite- $\mathrm{FeO}(\mathrm{OH})$, as shown in Figures 6 and 7.
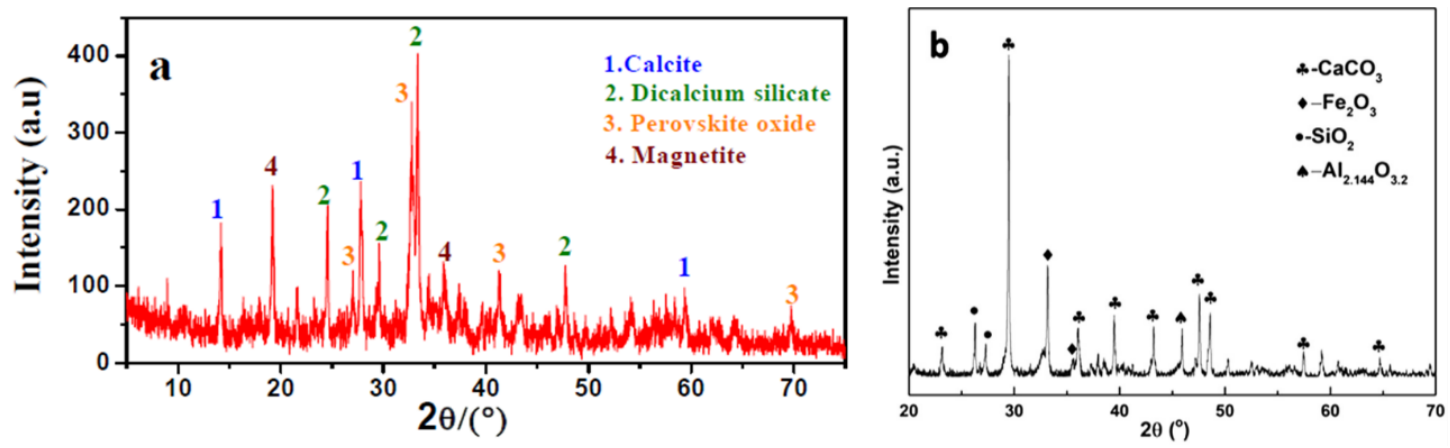

Figure 6. Mineral compositions of bauxite residue from sintering process: a [77], b [78].
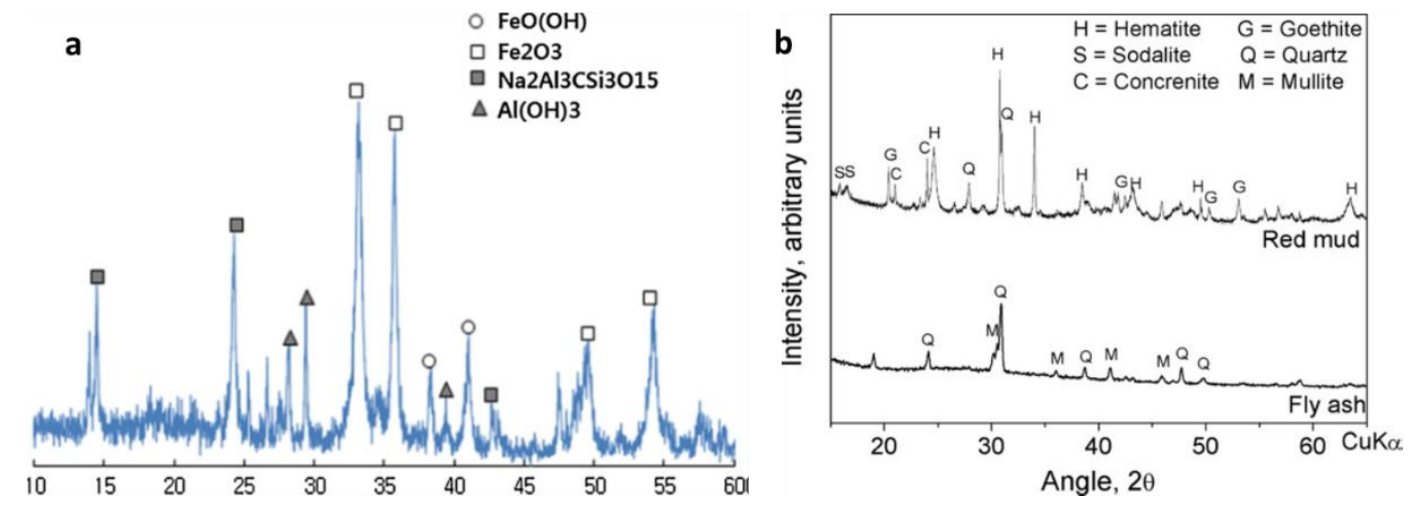

Figure 7. Mineral components of bauxite residues from the Bayer process: a [79], b [18].

\subsection{Physical properties of red mud}

For practical applications, most research concerns the fineness and grain size of red mud to replace natural powder materials used in products. The particle size of red mud is normally in the range of $0.1 \mu \mathrm{m}-100 \mu \mathrm{m}$, which can be detected by different methods. Kumar et al. investigated the grain size distribution of red mud with the help of a laser particle size analyzer and found that the particle diameters $X_{10}, X_{50}$ and $X_{90}$ of red mud were $0.37,1.57,56.88 \mu \mathrm{m}$ and its particle size was significantly lower and distribution narrower than that of the fly ash used in concrete, as shown in Figure 8(a) [18]. He et al. determined the particle size distribution of red mud based on the Standard Test Method for Particle-Size Analysis of Soils (ASTM D422-63) with the mean particle size $\left(D_{50}\right)$ located at $6.3 \mu \mathrm{m}$, while the coarse particles $(>75 \mu \mathrm{m}$ ) content accounted for $24 \%$, as shown in Figure 8(b) [80]. Zhang et al. compared the grain size distribution of red mud from the Bayer and sintering processes by using a laser particle size analyzer, as shown in Figure 9 [69]. The particle size distribution of the Bayer red mud was wider than the sintering red mud and the Bayer red mud containing more fine particles with a grain size under $10 \mu \mathrm{m}$. It is noticed that the red mud tends to aggregation once exposed to air as the particle becomes coarser even after sieving through $0.075 \mathrm{~mm}$. The natural fine grain behavior of red mud makes it easier to be mixed with other powder materials for various applications. 

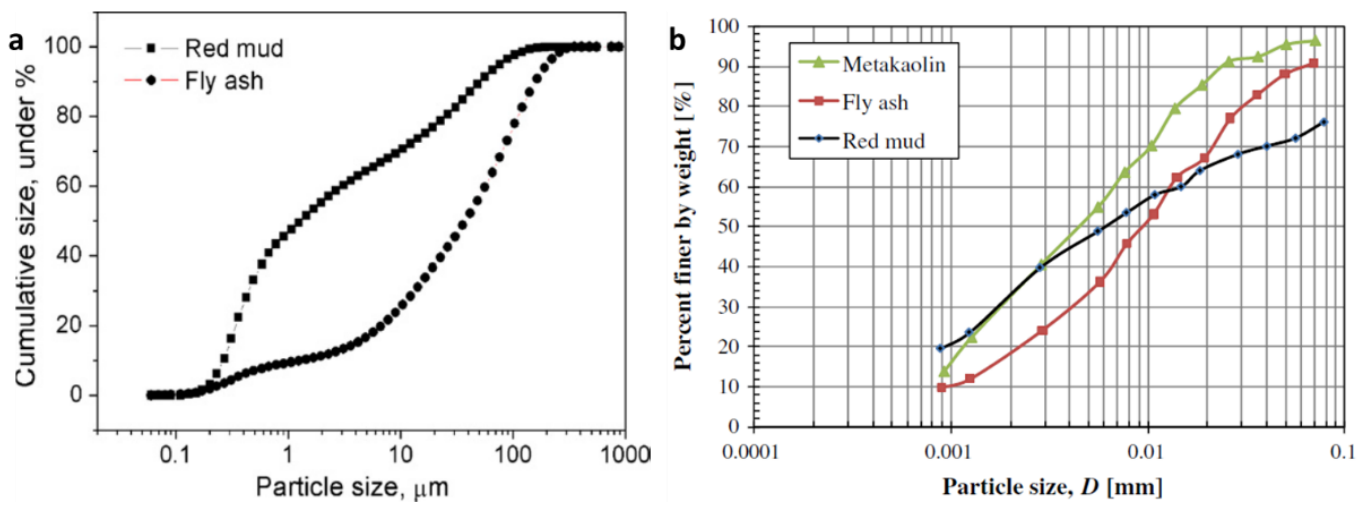

Figure 8. Particle size distribution curves of red mud obtained from different methods: (a) laser particle size analyzer [18]; (b) ASTM D422-63 [80].

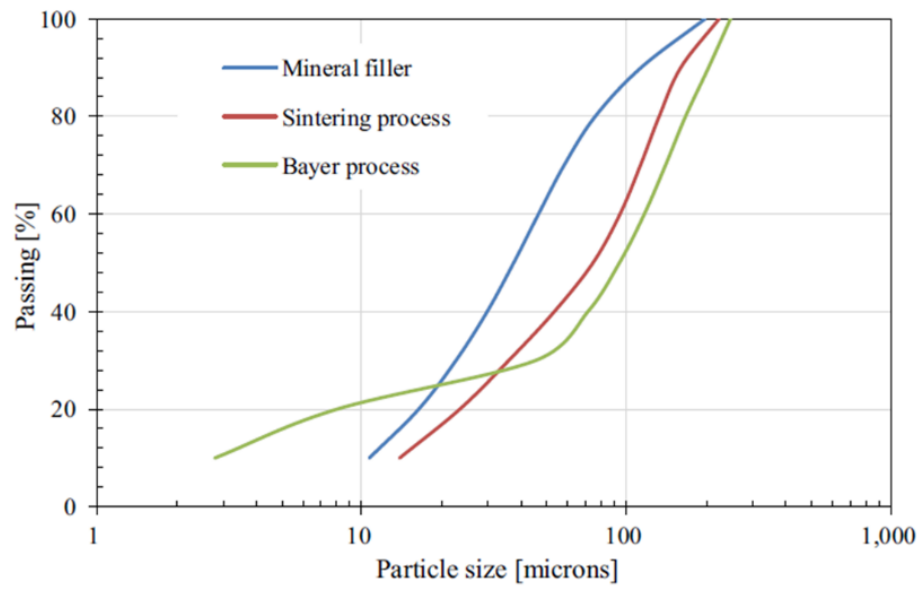

Figure 9. Particle size distribution of red mud from the sintering and Bayer processes [69]

Moreover, as a fundamental property, the morphology of red mud has been widely characterized by many researchers with the application of scanning electron microscopy (SEM), as presented in Figure 10. The microscopy reveals that red mud is composed of fine particles with the particle size ranging from a few microns to dozens of microns. The red mud is characterized as irregular shapes including flaky and spherical particles [81]. Normally, big aggregates consist of much smaller particles due to agglomeration. Particles are identified as amorphous substances (poorlycrystallized) and relatively dispersed and disordered [82]. Because of the particle agglomeration, there are spaces between fine particles. For comparison to mineral filler of limestone powder in asphalt, the pore size distribution and the specific surface area of red mud were also investigated, as shown in Figure 11. It is indicated that, for similar particle size level, the specific surface area of red mud was obviously larger than that of the limestone powder. The porous nature as well as the high specific surface area of red mud would contribute to its adsorption capacity as well as interfacial bonding behavior. 

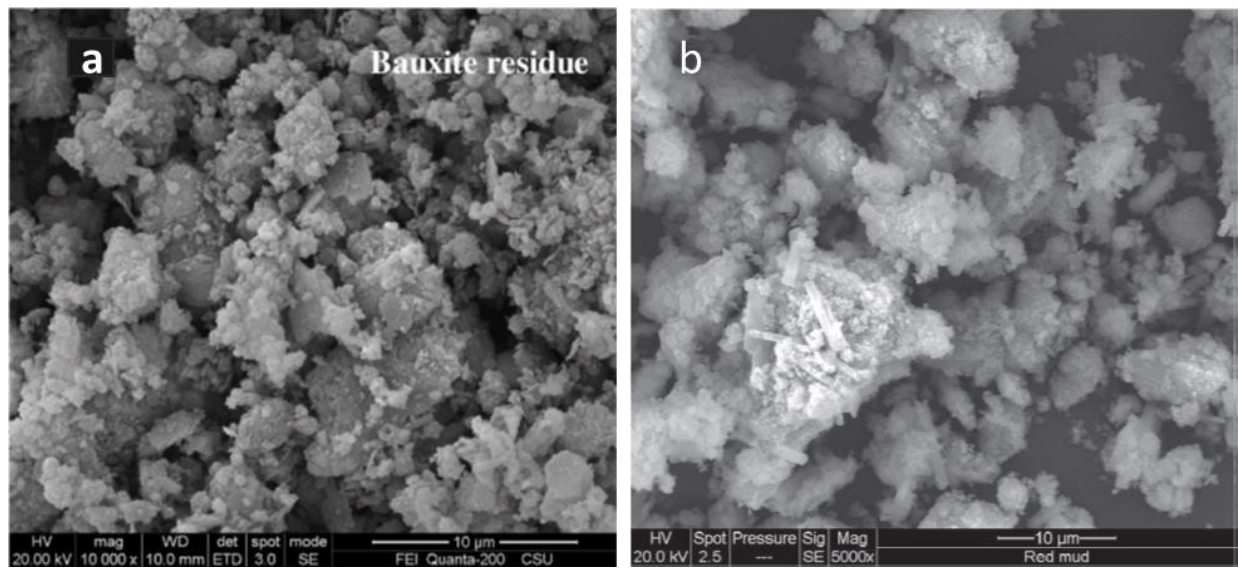

Figure 10. Scanning electron micrograph of red mud: (a) [82]; (b) [80].

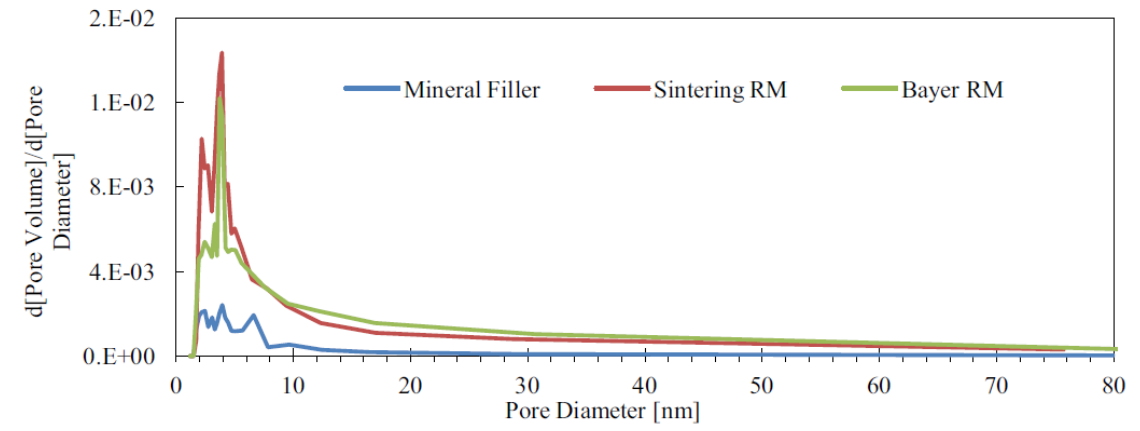

Figure 11. The derivative pore size distribution curves of mineral filler and red mud [69]

\subsection{Environmental impacts of red mud}

Based on the literature, the environmental influence of red mud normally focuses on its relatively high $\mathrm{pH}$ values, heavy metals leaching and radiation safety.

Because of the high alkalinity, heavy metals presence and trace radioactive elements of red mud, it is normally realized as a hazardous material and poses serious threats to the environment. In accordance with Basel Convention on the Control of Trans boundary Movements of Hazardous Wastes and Their Disposal, "Hazardous waste" is defined as a category of a material which possesses one or more hazardous behaviors, such as corrosivity, toxicity, ignitability, reactivity and/or infectivity. With respect to red mud, its ignitability, reactivity as well as infectivity are relatively lower than that of normal hazardous materials. So, the toxicity and corrosivity are the two main parameters to appraise the environmental impacts of red mud. The Toxic Characteristic Leachability Procedure (TCLP) is commonly used to characterize the toxicity of red mud by measuring the leaching concentration of heavy metal elements. Table 3 presents the heavy metal contents of red mud from different aluminum plants compared with the Chinese Identification standard for hazardous wastes (GB5085.1-7, 2007). It is clear that the toxic element contents of all red muds are lower than the Standard level. So, these red muds cannot be defined as a hazardous waste, but a general industrial solid waste. Consequently, in the Chinese National Catalogue of Hazardous Wastes issued by the Chinese government in 2008, red mud is not categorized as a hazardous material.

Due to the presence of heavy metal elements, the radiation safety of red mud is also evaluated. The safety thresholds of red mud, internal exposure index $\left(I_{R a}\right)$ and external exposure index $\left(I_{r}\right)$, are all under the threshold limits of the Chinese standard Limits of Radionuclides in Building Materials 
(GB 6566-2010). It is therefore indicated that utilizing red mud as a building material could meet the national radioactive requirements [69].

The environmental impacts of red mud are mainly because of its high $\mathrm{pH}$ value. The $\mathrm{pH}$ value of red mud is normally from 9 to 12.5 and can reach the standard threshold limit level (12.5) [18]. The leaching and precipitating of highly alkaline liquid from red mud is a risk to contaminating surface and underground water resources [83]. A massive discharge of red mud as a result of storage structural failure and other accidents leads to environmental disasters because of its high alkaline nature. In 2010, a red mud leakage accident in Hungary led to the death of 10 people and hundreds seriously burned [84]. After this tragedy, the Hungarian government declared that the red mud is poisonous and its corrosivity is attributed to its strong alkalinity [85].

Due to its small size, red mud is able to easily cause dust under the action of wind and thus affect air quality [86]. Moreover, evaporation of high alkali components from red mud could accelerate the formation of high alkaline rainfall, which eventually threatens soil and water [87].

Table 3. Leaching concentrations of toxic metal elements in the leachates of red mud and the standard thresholds [7][69].

\begin{tabular}{|c|c|c|c|c|c|c|c|c|}
\hline \multirow{2}{*}{$\begin{array}{c}\text { Toxic heavy } \\
\text { metals }\end{array}$} & \multirow[b]{2}{*}{ Unit } & \multicolumn{6}{|c|}{ Red mud from different aluminum plants } & \multirow{2}{*}{$\begin{array}{c}\text { Toxicity } \\
\text { thresholds }\end{array}$} \\
\hline & & $\begin{array}{c}\text { Henan } \\
\text { Bayer }\end{array}$ & $\begin{array}{c}\text { Guangxi } \\
\text { Bayer }\end{array}$ & $\begin{array}{c}\text { Shanxi } \\
\text { Combined }\end{array}$ & $\begin{array}{c}\text { Indonesia } \\
\text { Bayer }\end{array}$ & $\begin{array}{c}\text { Shandong } \\
\text { Sintering }\end{array}$ & $\begin{array}{c}\text { Shandong } \\
\text { Bayer }\end{array}$ & \\
\hline $\mathrm{Cd}$ & $\mathrm{mg} / \mathrm{L}$ & $<0.003$ & $<0.003$ & $<0.003$ & $<0.003$ & $\mathrm{~N}$ & $\mathrm{~N}$ & 1 \\
\hline $\mathrm{Pb}$ & $\mathrm{mg} / \mathrm{L}$ & $<0.05$ & $<0.05$ & $<0.05$ & $<0.05$ & 0.046 & 0.813 & 5 \\
\hline $\mathrm{Cr}$ & $\mathrm{mg} / \mathrm{L}$ & 0.16 & 0.12 & $<0.01$ & $<0.01$ & 0.457 & 8.624 & 15 \\
\hline As & $\mathrm{mg} / \mathrm{L}$ & $<0.1$ & $<0.1$ & $<0.1$ & $<0.1$ & 0.682 & 0.180 & 5 \\
\hline $\mathrm{Cu}$ & $\mathrm{mg} / \mathrm{L}$ & $<0.01$ & $<0.01$ & 0.027 & 0.015 & 0.643 & 2.776 & 100 \\
\hline $\mathrm{Zn}$ & $\mathrm{mg} / \mathrm{L}$ & $<0.006$ & $<0.006$ & $<0.006$ & $<0.006$ & 1.203 & 3.303 & 100 \\
\hline $\mathrm{Ni}$ & $\mathrm{mg} / \mathrm{L}$ & $<0.01$ & $<0.01$ & $<0.01$ & $<0.01$ & 1.546 & 1.062 & 5 \\
\hline
\end{tabular}

\section{Utilization of red mud in road bases}

A road pavement is a type of multiple-layer structure, which is normally made up of asphalt mixture surface layers or a concrete surface layer, road base layers and road sub-base layers. As a layered system, each layer bears and carries the load from the above layer and transfers the load to the next layer below [88][89]. As semi-rigid material has high strength, good moisture stability and low cost, it is a commonly used as a road base material for asphalt pavements in China [90]. The semi-rigid base material, as a hydraulic material, is produced by homogenously blending predetermined ratios of water, aggregates (coarse and fine) and hydraulic materials, followed by paving and compaction stages to construct a semi-rigid road base [91][92]. In a semi-rigid pavement structure system, the semi-rigid road base plays an important role for structural bearing capacity and has to sustain repeated traffic loading. In general, the two commonly used semi-rigid road base materials are lime-fly ash stabilized aggregate (LFSG) and cement stabilized aggregate (CSG). With the view to seeking a feasible potential for red mud utilization, there are several investigations that have been carried out to employ red mud as a secondary material instead of the hydraulic material for road base construction.

Liu et al. investigated the strength development of red mud stabilized by lime and fly ash in order to demonstrate the feasibility of using red mud for road base construction [93]. An orthogonal experimental method was employed to analysis the influence of red mud types and dosages on 
the unconfined compressive strength (UCS) of the stabilized materials. The experimental findings indicated that the stabilized material with red mud dosage of over $50 \%$ can meet the Chinese standards strength requirement for road base materials [94]. This is because the boehmite $(\gamma-$ AlO(OH)) and goethite $(\mathrm{FeO}(\mathrm{OH}))$ in red mud participated in a reaction with active materials in fly ash and lime, such as $\mathrm{Ca}(\mathrm{OH})_{2}$ and tricalcium aluminate $\left(\mathrm{Ca}_{3} \mathrm{Al}_{2} \mathrm{O}_{6}\right)$, to produce a short-term reaction with hydrated silica aluminates like gismondine $\left(\mathrm{CaAl}_{2} \mathrm{Si}_{2} \mathrm{O}_{8} \cdot 4\left(\mathrm{H}_{2} \mathrm{O}\right)\right)$ and $\mathrm{CSH}$ being generated after a long-term reaction. The continuous hydration process with curing generated more hydration products, which consequently increases UCS [95].

Mukiza et al. investigated the strength development of a type of eco-friendly material used for road base prepared with $30 \%$ of red mud [19]. By optimizing the mix ratios, the stabilized material obtained UCS of $5.92 \mathrm{MPa}$ and $6.66 \mathrm{MPa}$ after 7 days and 28 days curing, respectively. Long-term soaking curing also contributes to the growth of UCS because the alkaline environment promotes the formation of hydration products. The microstructure analysis revealed that the formation of $\mathrm{C}$ $\mathrm{S}-\mathrm{H}, \mathrm{C}-\mathrm{A}-\mathrm{S}-\mathrm{H}, \mathrm{N}-\mathrm{A}-\mathrm{S}-\mathrm{H}$ gels, and ettringite with prolonged curing time is responsible for the strength development, as shown in Figure 12. In addition, the $\mathrm{Ca}_{2} \mathrm{SiO}_{4}, \mathrm{Ca}_{3} \mathrm{SiO}_{5}$ and $\mathrm{AlO}_{2}^{-}$present in red mud are fully involved in hydration reactions.
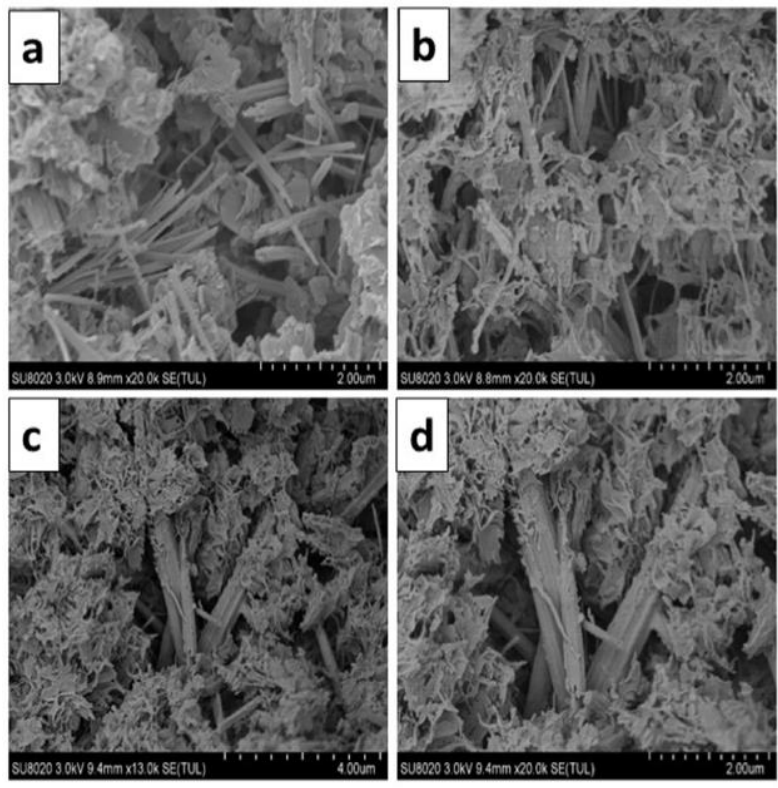

Figure 12. Micrographs of stabilized material prepared with red mud cured for $3 d(a), 7 d(b)$ and $28 d$ (c and d)

Zhang et al. [96] utilized red mud, electrolytic manganese (EMR) and carbide slag (CS) as main raw components to produce a road base material. The developed road base material with the optimized material ratios obtained 7-day UCS of 5.6 MPa, which is higher than the strength threshold (3-5 MPa) of the Chinese standards for highway road base. This is because the incorporation of red mud supplied a high alkalinity environment and promoted the formation of hydraulic substances (C-A-S-H gel and AFt), which in turn contributed to the internal bond strength of the road base materials. In addition, the freezing-thawing test and wetting-drying cycle test revealed that this road base materials had qualified frost resistance and durability. After laboratory testing, the developed road base material was used for road base construction, as shown in Figure 13. The field test indicated that the cored samples after 7 days curing obtained even higher 
strength than that in the laboratory. Using red mud to produce road base material not only consumes a significant amount of industrial solid waste, but also delivers a new idea for synergistic utilization of related solid wastes.

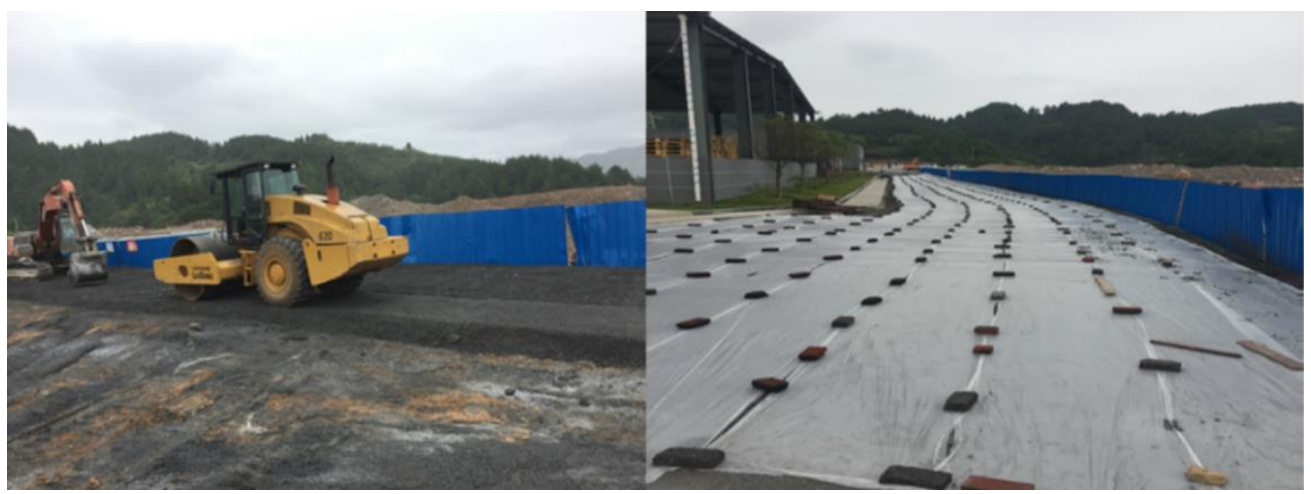

Figure 13. Field-test for road base material prepared with red mud [96]

Hu et al. [97] studied the feasibility of utilizing red mud as an original composition to prepare geopolymer-stabilized base material in pavements. Geopolymers are normally defined as inorganic binders prepared by alkali activation of aluminosilicates by means of complex dissolutionreorientation-solidification reactions [98]. The final products of geopolymer reaction are some amorphous alkali aluminosilicate gels which contribute to strength development [99]. Because red mud possesses a certain amount of $\mathrm{Al}_{2} \mathrm{O}_{3}$ and $\mathrm{SiO}_{2}$, it has the potential to be applied as a raw material for geopolymer preparation. Red mud and class $\mathrm{F}$ fly ash can be selected to produce geopolymer stabilized aggregate base and the influence of curing conditions (temperature and moisture) on final material strength was also studied. The results showed that the 7-day curing UCS of geopolymer-stabilized aggregate base was $10.5 \mathrm{MPa}$ and this value kept growing with the increase of curing temperature. Based on the strength threshold (3-5 MPa) of Chinese standards for highway road base, the geopolymer-stabilized base material prepared with the incorporation of red mud easily reached the strength requirement. In terms of the strength formation mechanism, the incorporation of the high alkalinity red mud could contribute to the geopolymerization process, which in turn forms a dense structure with a high strength.

The research mentioned above indicated that the utilization of red mud as a raw material in road base construction is feasible and able to obtain qualified UCS, frost resistance and durability performance in the laboratory. However, during the long-term service life, the road base is subjected to repeated traffic loading and serious environmental attacks, which might lead to various defects such as micro-cracks and loosened structured layer. It is thus especially important to characterize the long-term performance of road base materials prepared with red mud, including long-term laboratory tests and field observation. Although the leaching behavior and radionuclide content of road base materials with red mud have proved to be lower than that of the related standard thresholds [100][101], it is still necessary to minimize the long-term impact on the environment by various measures in practice.

\section{Utilization of red mud in asphalt mixtures}

Asphalt mixture used in asphalt pavements is a composite material prepared by using aggregates, mineral filler and bitumen at predetermined ratios in terms of blending and then laid and 
compacted into a pavement layer. The mineral filler is an important component in asphalt mixtures, which extends the effective adhesive binder required to bind the aggregates, and increases the stiffness of asphalt mastic and asphalt mixtures [102]. Generally, the mineral filler used for asphalt mixture production is obtained from crushing and ball-milling of limestone boulders. With the increasing awareness of environmental protection and shortage of natural resources, several alternative powder materials have been incorporated into asphalt mixtures as replacement mineral fillers, such as fly ash, diatomite, cement and steel slag filler [103]. In recent years, using red mud in asphalt mixtures to replace mineral filler has also attracted attention. These investigations can be briefly separated into two categories: red mud in asphalt mastics and red mud in asphalt mixtures.

\subsection{Red mud in asphalt mastic}

In asphalt mixtures, mineral filler and bitumen are assembled to form asphalt mastics and fill the interstices between aggregates [104][105]. The presence of mineral filler stiffens the bitumen which in turn improves the mechanical performance of asphalt mixtures [106]. Due to its specific physical, chemical and geometrical behavior, the mineral filler has an effect on the mechanical and rheological properties of asphalt mastics [107]. Hence, in order to utilize red mud in asphalt mixtures, its influence on properties of asphalt mastic was first investigated by several researchers. The influence of red mud dosages on conventional properties (penetration, softening point and ductility) of asphalt mastic was investigated by Fu et al. [108]. The results demonstrated that the incorporation of red mud from $3 \%$ to $15 \%$ improved deformation resistance and reduced temperature sensitivity. However, the incorporation of red mud reduced the asphalt ductility which in turn had a detrimental effect on its cracking resistance at low temperature. Based on the microtopography analysis, the small red mud particle with a large surface area absorbed part of the oil in the bitumen and improved the adhesion between them, which in turn enhanced the consistency of asphalt mastics. Zhang et al. [69] evaluated the replacement of mineral filler with red mud on the penetration and softening point of asphalt mastics, as shown in Figure 14. Due to the replacement of mineral filler by red mud, the softening point increased but the penetration decreased with increasing red mud percentage. It demonstrated that the incorporation of red mud may has positive effects on the high-temperature performance improvement of asphalt mixtures. With respect to the same red mud dosage, the mastics with the sintering red mud presented higher softening point and lower penetration results in comparison with the Bayer red mud. The temperature susceptibility of asphalt mastic was characterized by using the penetration index ( $\mathrm{PI})$, which was calculated using Equation 1. The PI results indicated that the incorporation of red mud improved the elasticity of asphalt mastic which in turn had a positive effect on the rutting resistance of asphalt mixture.

$P I=\frac{1952-500 \log \left(\text { Pen }_{25}\right)-20 S P}{50 \log \left(\text { Pen }_{25}\right)-S P-120}$

where, $\mathrm{Pen}_{25}$ is the penetration at $25^{\circ} \mathrm{C}(0.1 \mathrm{~mm})$ and $\mathrm{SP}$ is the softening point $\left({ }^{\circ} \mathrm{C}\right)$ 

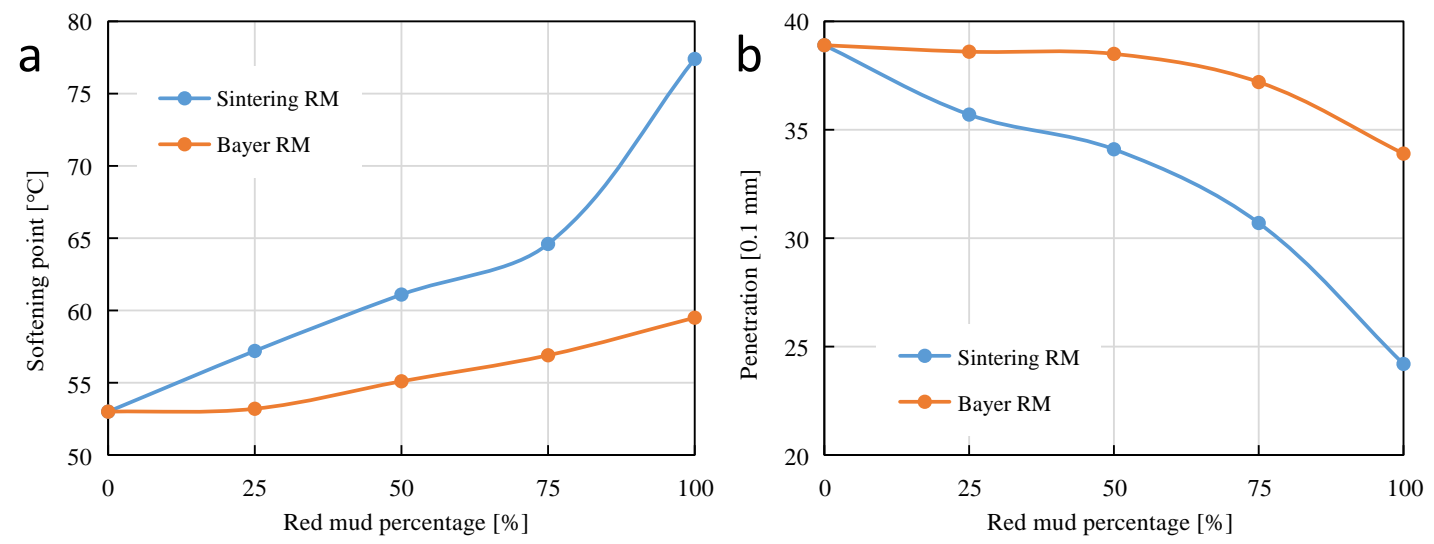

Figure 14. Softening point (a) and Penetration results of asphalt mastic prepared with the red mud replacing mineral filler [69]

Zhang et al. [109] characterized the influence of red mud with different FBv (filler-bitumen ratio by volume) on the viscosity of asphalt mastics at high temperature when compared with conventional asphalt mastic with limestone filler, by using the Brookfield Viscometer. The results indicated that the asphalt mastics prepared with red mud exhibited higher viscosity and worse workability than those with limestone filler and fly ash. This is because the porous structure and large Rigden's voids of red mud can absorb and fix more free asphalt which in turn leads to high viscosity and worse workability [110]. Taking the workability in consideration, the optimum FBv of asphalt mastic with the addition of red mud was determined.

The influence of red mud on rheological properties of asphalt mastic was evaluated by using the dynamic shear rheometer (DSR). Zhang et al. [111] evaluated the complex modulus and phase angle of asphalt mastics composed of the same dosage of limestone filler, red mud and three other composite fillers by using frequency sweep tests, as shown in Figure 15. The results indicated that the complex modulus of asphalt mastic with red mud was higher than that of the asphalt mastic with limestone filler. Furthermore, the asphalt mastics prepared with red mud presented slightly lower phase angles than those prepared with limestone filler. It is suggested that red mud has the potential to improve the permanent deformation and elastic behavior of asphalt mastics. Apart from that, the rutting parameter $\left(\mathrm{G}^{*} / \sin \delta\right)$ was investigated by different researchers to evaluate the high-temperature performance of asphalt mastics [111][112]. The multiple stress creep and recovery (MSCR) test revealed that the asphalt mastics prepared with red mud showed lower $\mathrm{J}_{\mathrm{nr}}$ than that of the conventional asphalt mastics with limestone and fly ash [109]. The researchers obtained consistent results, indicating that the high temperature performance of the asphalt mastics containing red mud is superior to that of the asphalt mastics prepared with the conventional mineral filler. 


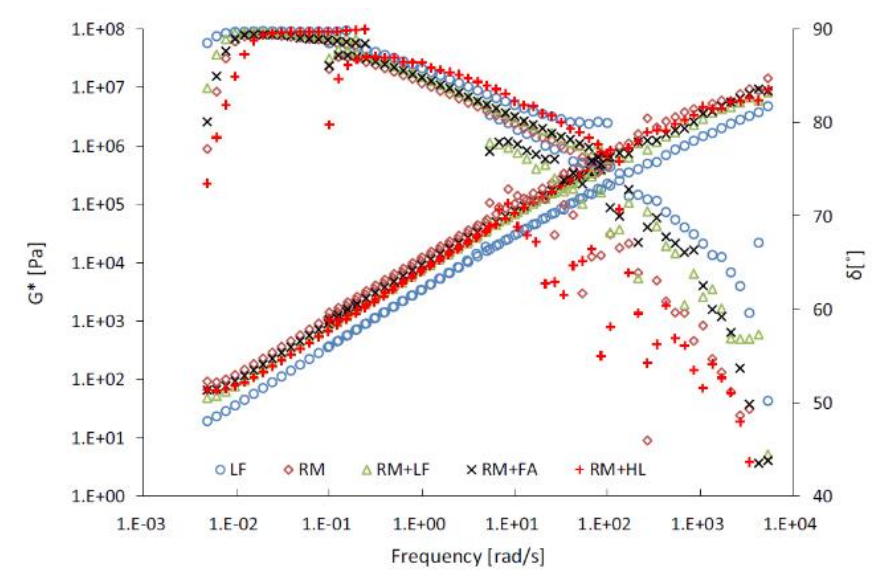

Figure 15. Master curves of complex modulus and phase angle of asphalt mastics containing

different types of mineral fillers [111]

With respect to characterizing the behavior of asphalt mastics with red mud at low temperature, the Bending Beam Rheometer (BBR) and Direct Tension (DT) tests were employed. Based on the BBR test, the asphalt mastic prepared with red mud exhibited larger creep stiffness modulus (S) and smaller creep slope ( $m$ value) in comparison with that prepared with limestone filler at the filler-bitumen ratio of 0.9, as shown in Figure 16 [112]. This indicated that the addition of red mud had detrimental effects on the low temperature cracking resistance of asphalt mastic. The DT test obtained a similar trend with the asphalt mastic prepared with red mud having a smaller tensile elongation at break than that of the mastic prepared with limestone filler, as shown in Figure 17 [78]. In order to improve the cracking resistance of asphalt mastics prepared with red mud, hydrated lime and white mud were incorporated together. The white mud is a type of solid waste generated from paper manufacturing, which is mainly composed of $\mathrm{CaCO}_{3}$ and possesses some impurities such as $\mathrm{Na}_{2} \mathrm{O}, \mathrm{K}_{2} \mathrm{O}$, and $\mathrm{Fe}_{2} \mathrm{O}_{3}$. The results indicated that the incorporation of hydrated lime and white mud can both contribute to the low temperature performance of asphalt mastics prepared with red mud.

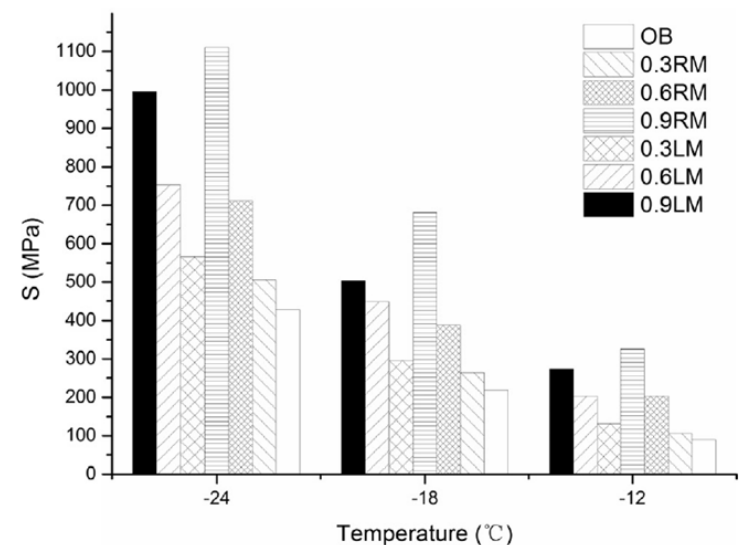

(a)

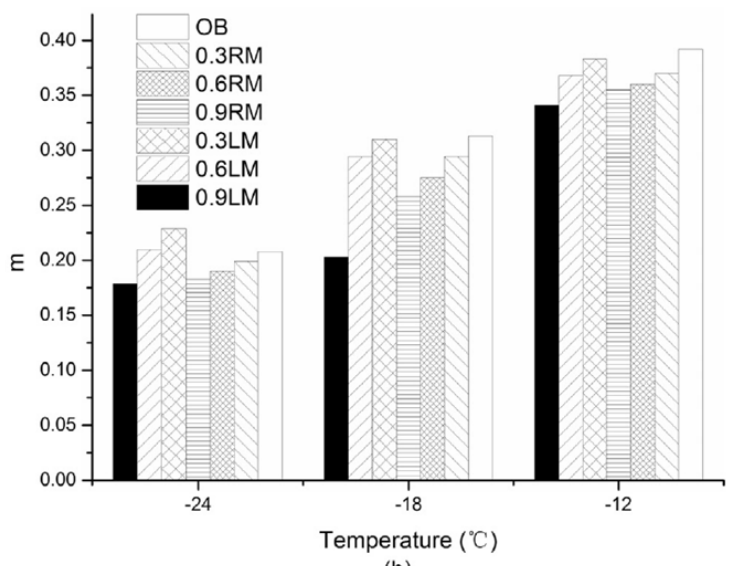

(b)

Figure 16. BBR test results of asphalt and asphalt mortar prepared with red mud [112] 


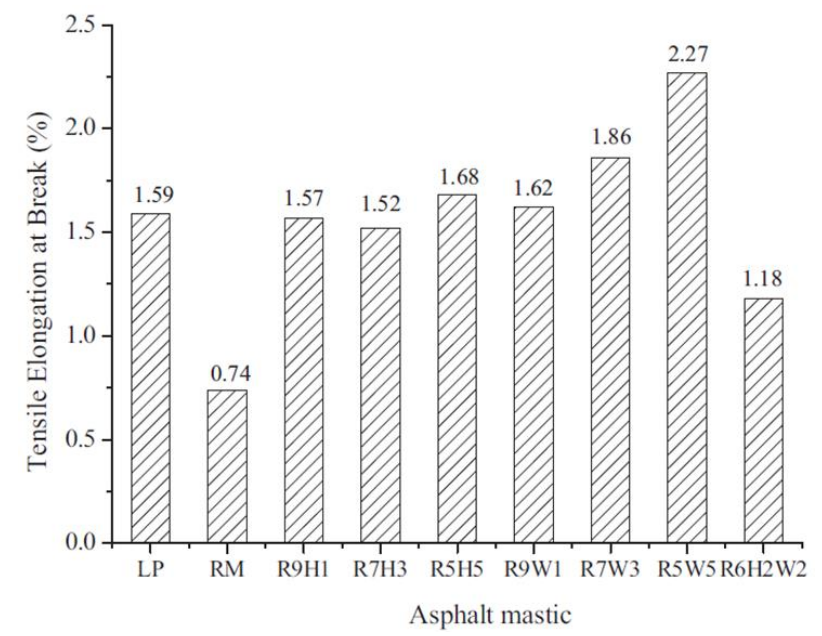

Figure 17. Tensile elongation at break of different asphalt mastics at $-12^{\circ} \mathrm{C}[78]$.

The bond strength between aggregate and asphalt mastic is a crucial indicator to characterize the capability of the related asphalt mixtures to resist moisture damage [113]. After incorporating red mud, the bonding behavior of the aggregate-mastic interface in both dry and wet conditions were characterized by different methods. The Pull-Off Tensile Strength (POTS) test was applied to investigate the adhesive ability of the asphalt mastics-aggregate interface, as shown in Figure 18 [110]. The results indicated that the adhesion of asphalt mastic was enhanced with the increase of filler-bitumen ratio in the dry condition, while a higher filler-bitumen ratio had detrimental effects on the adhesion behavior under moisture conditions. Under the same filler-bitumen ratio, the asphalt mastic with red mud showed higher adhesion strength than that of the limestone filler, regardless of dry or wet condition. This research also demonstrated that the adhesive property of the asphalt mastic was dominated by the chemical composition of the filler, but not the physical features. The bonding behavior of asphalt mastics investigated by Zhang et al. [78] obtained different results with the asphalt mastic containing red mud showing lower bonding strength than that prepared with limestone powder subjected to moisture attack. It is suggested that the incorporation of red mud has a detrimental effect on the service durability of the corresponding asphalt mixtures, especially in the pluvial region. However, the mixed use of red mud with white mud can improve the moisture resistance of aggregate-asphalt mastic bonding under both shortterm and long-term moisture conditioning, as shown in Figure 19.
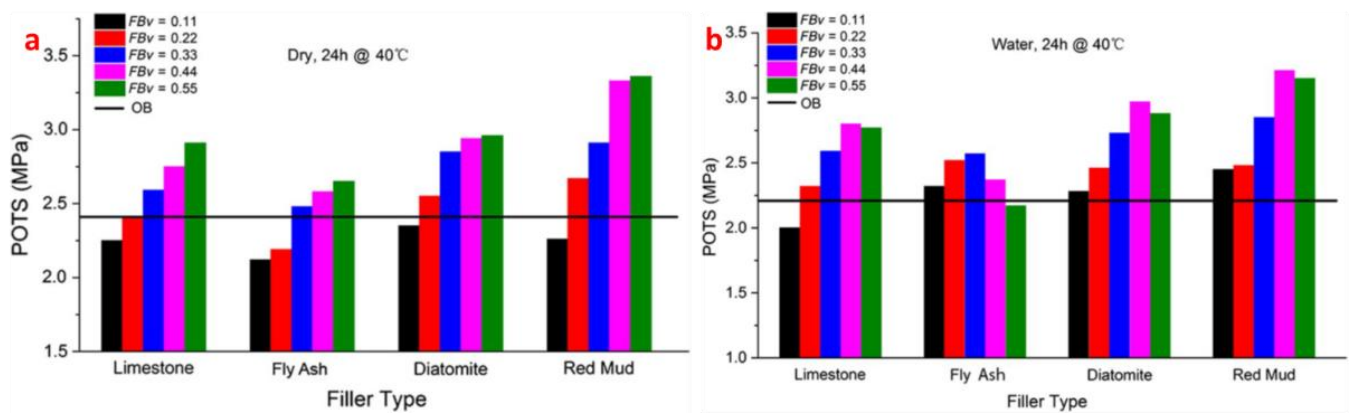

Figure 18. BBS test results of the asphalt and mortar in dry condition (a) and moist condition (b) [110]. 


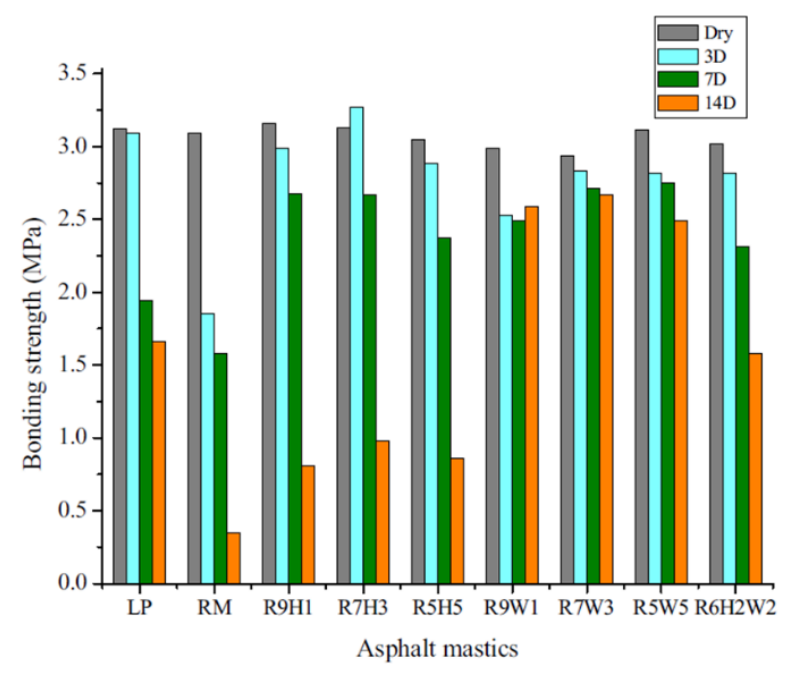

Figure 19. Bonding strength of different asphalt mastic-aggregate substrate interfaces in dry and wet conditions [78]

Based on the results mentioned above, the addition of red mud resulted in improved asphalt mastic stiffness, such as higher softening point, higher complex modulus and higher viscosity, because of the porous nature of red mud. The high stiffness of asphalt mastic with red mud indicates its potential of rutting resistance of related asphalt mixtures, but the workability of asphalt mixtures during mixing processes then becomes a big concern. With respect to the influence of red mud on the low-temperature cracking resistance and the moisture resistance of asphalt mastics, they can be improved by adding a certain amount of active filler, such as hydrated lime or white mud.

\subsection{Red mud in asphalt mixture}

As the asphalt mixture is the product for road surfacing in the pavement, its mechanical performance is the final criterion to characterize the probability of utilizing red mud as a replacement of mineral fillers. The influence of red mud on the mechanical properties of asphalt mixtures was investigated by many researchers.

Choudhary et al. [114] prepared Marshall compacted specimens by using red mud and found that the bulk specific gravities of mixtures prepared with red mud $(2.505 \mathrm{~g} / \mathrm{cc})$ was higher than that of the normal mixture $(2.469 \mathrm{~g} / \mathrm{cc})$. The increase of red mud content also resulted in an increase in the bulk density of the asphalt mixture [115]. This is because the fine particle size of red mud acts as a binder extender which provides more workability to obtain a higher density. Moreover, the higher specific gravity of red mud plays a role in contributing to a higher density of asphalt mixture. Because of the higher porosity of red mud, red mud mixtures always obtain a higher air void content than that of conventional mixtures at similar binder contents. In addition, the OAC (the binder content corresponding to $4 \%$ air voids of compacted Marshall specimens) of red mud mixture (5.66\%) was higher than that of the conventional mixture (5.34\%) [116]. This indicates that using red mud to prepare asphalt mixtures could consume a higher amount of bitumen, which in turn has the potential to increase the overall cost of the mixture. The lower voids filled with bitumen (VFB) of the red mud mixture demonstrates its potential to be used in hot climate regions due to its lower possibility of bleeding.

Lima et al. [117] investigated the influence of red mud on the rutting resistance of asphalt mixtures 
based on the French standard NFP 98-253-1. The results indicated that substituting the mineral powder for $3 \%$ of red mud reduced the permanent deformation from $6.10 \%$ to $5.31 \%$, as shown in Figure 20. The superior rutting resistance of asphalt mixtures prepared with red mud was also verified based on the Marshall Stability test [116]. The parameter of Marshall Quotient (MQ), which is defined as the ratio of Marshall Stability $(\mathrm{kN})$ to flow $(\mathrm{mm})$ was employed to characterize the asphalt mixture's resistance to permanent deformation. The results indicated that the MQ value of asphalt mixtures prepared with red mud was higher than that of the conventional mixture, which in turn has better rutting resistance. This is the fact that the finer nature of red mud enables it to distribute uniformly in asphalt mixtures and form an integrated structure [118]. In addition, the chemical composition of red mud may also contribute to the superior high-temperature performance of related asphalt mixtures [112].

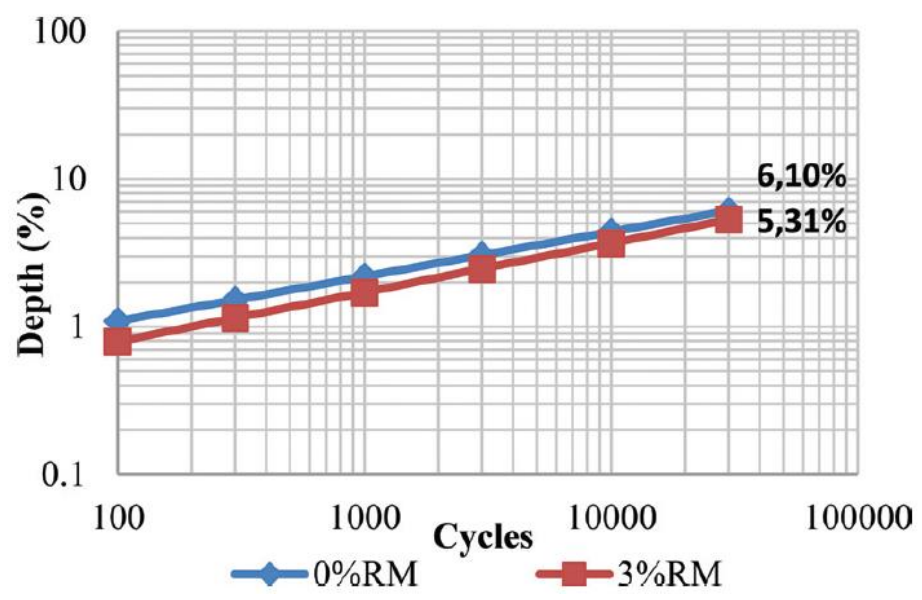

Figure 20. Permanent deformation performance of compacted asphalt mixtures prepared with red mud [117]

The influence of red mud on moisture susceptibility of asphalt mixtures was characterized by using the Retained Marshall Stability (RMS) based on the ASTM D1075-11 specification [119]. Choudhary et al. [116] found that the RMS value of the mineral filler mixture (88.57\%) was higher than that of the red mud mixture $(82.28 \%)$, but both of them satisfied the criterion of the minimum requirement (75\%) [120]. In another publication, Choudhary et al. [114] employed different waste materials as fillers and compared their influences on moisture susceptibility of asphalt mixtures by using the RMS parameter. The results indicated that the RMS of red mud mixture (89.21\%) was lower than that of the conventional mixture (93.56\%), but the result was higher than that of mixture prepared with glass powder (82.71\%), copper tailings (88.56\%) and rice straw ash (80.21\%). This correlated well with the bonding behavior of asphalt mastics that the asphalt mastic with red mud showed a lower bonding strength than that of the mixture with limestone powder after moisture conditioning [78]. In order to evaluate the raveling resistance of asphalt mixture with red mud as the filler, the Cantabro durability test was performed by Choudhary et al. [116], as shown in Figure 21. The weight loss of mixtures indicates the loss of adhesion after different curing conditions. It can be seen that both mixtures displayed good raveling resistance in the dry condition with a weight loss less than $5 \%$. However, the red mud mixture experienced a greater weight loss $(16.07 \%)$ than that of the mineral filler mixture $(4.74 \%)$ in the wet condition, indicating its worse raveling resistance. Zhang et al. [112] performed the Hamburg Wheel Tracking test to evaluate the moisture sensitivity and the rutting resistance of porous asphalt mixtures (air void content 18\%) prepared with red mud, as shown in Figure 22. The mixture prepared with red mud showed a lower 
rutting depth in comparison with that of the mixture prepared with limestone powder. This suggests that the porous asphalt mixture prepared with the red mud resulted in better moisture resistance.

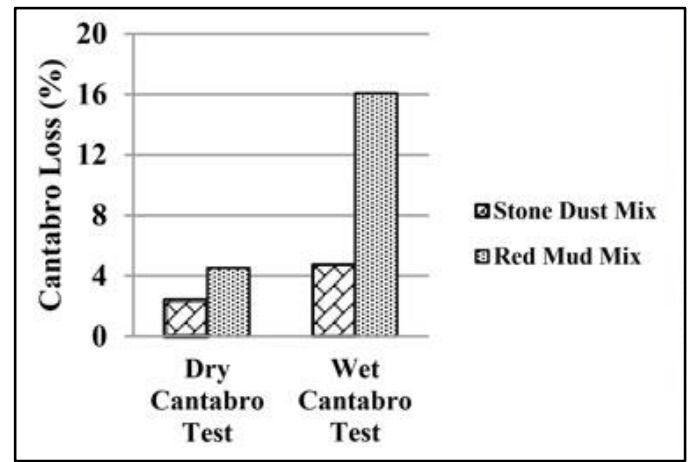

Figure 21. Average Cantabro weight losses of mixtures in both dry and wet conditions [116]

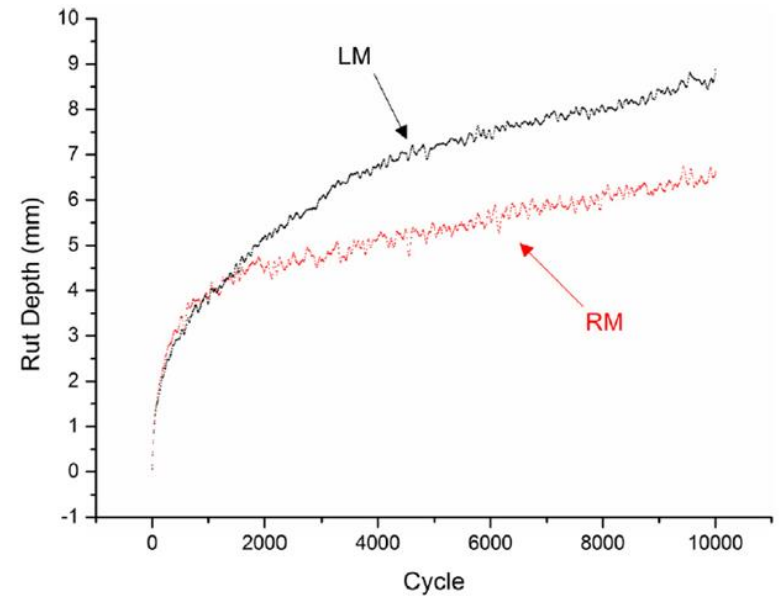

Figure 22. Rutting depth development of porous asphalt mixtures prepared with limestone filler and red mud [112]

The review on asphalt mixture performance demonstrated that the incorporation of red mud as the replacement of limestone filler has a positive effect on the mechanical behavior of the corresponding asphalt mixtures, such as high bulk density and good rutting resistance. With respect to moisture susceptibility and raveling resistance, many researchers found that the addition of red mud has a detrimental effect on these two parameters. So, how to improve the moisture resistance of red mud asphalt mixtures will be a future research focus. In addition, there is still a lack of research on mixture performance such as cracking resistance at low temperature, fatigue properties, as well as long-term durability.

\section{Conclusions and recommendations}

This paper focuses on a critical review on the utilization of red mud as a road material in pavements, including using red mud in road bases and asphalt mixtures. In terms of chemical oxide compositions, red mud has a high content of $\mathrm{CaO}, \mathrm{Fe}_{2} \mathrm{O}_{3}$, and $\mathrm{Al}_{2} \mathrm{O}_{3}$, which endows its more cementitious behavior and considers it as a construction material. With respect to physical features, red mud particles are porous and have a higher specific surface area than that of limestone powder, which contributes to its adsorption capacity and interfacial bonding properties. Referring to its environmental impacts, its toxic trace elements and radiation level are below the standard levels, which demonstrates that red mud is not categorized as a hazardous material. 
The utilization of red mud as a road base material in literature can be classified in two aspects consisting of the production of hydraulic-stabilized road base materials and geopolymer-stabilized materials. For hydraulic-stabilized materials in road bases, red mud is normally mixed with fly ash, hydrated lime and cement to form hydrated products (C-S-H, C-A-S-H, N-A-S-H gels). Referring to geopolymer-stabilized materials, red mud is participated in the dissolution-reorientationsolidification reactions and generates amorphous alkali aluminosilicate gels. Laboratory investigations indicate that it is feasible to use red mud as a raw material in road base construction with the required UCS, frost resistance and durability.

In asphalt mixtures, red mud is incorporated as a replacement of natural mineral fillers. In order to characterize the feasibility of utilizing red mud in asphalt mixtures, the influence of red mud on asphalt mastics was investigated. The addition of red mud was found to be able to improve the stiffness of asphalt mastics, such as improved softening point, complex modulus and viscosity. The high stiffness of asphalt mastics with red mud indicates its potential for rutting resistance of asphalt mixtures. With respect to the influence of red mud on low-temperature cracking resistance and moisture resistance of asphalt mastics, adding a certain amount of active filler, such as hydrated lime or white mud, can help to improve these two properties. The incorporation of red mud as the replacement of limestone filler has some positive effects on mechanical properties of asphalt mixtures such as good rutting resistance. With respect to moisture susceptibility and raveling resistance, the addition of red mud might have detrimental effects on these two parameters.

Based on this overview, the authors believe that further research is needed in certain directions so as to promote the application of red mud as a road material in pavements:

1) In terms of red mud as road base materials, although UCS, frost resistance and durability were proved to meet the requirement in the laboratory, the long-term performance during the service lifetime is still not clear. It is necessary to qualify the long-term service performance of road base materials prepared with red mud by using accelerated laboratory evaluation or trial testing and road observation.

2) With respect to asphalt mastics and mixtures, the incorporation of red mud had detrimental effects on their bonding strength, moisture susceptibility and raveling resistance. How to improve these properties of red mud asphalt mixtures, in terms of surface modification or using other active powders, will be a future research focus. In addition, the adhesion mechanism between bitumen and red mud in both dry and wet conditions still needs further clarification.

3) Moreover, previous research mainly focused on the influence of red mud on volume performance, rutting resistance and moisture susceptibility of asphalt mixtures. How the red mud influences the low-temperature cracking resistance, fatigue properties and long-term durability of asphalt mixtures should also be a future research direction.

4) The high alkalinity of red mud is still a big challenge for safe utilization as a road material in pavements. Further studies are needed on investigating applicable and economic techniques to neutralize or solidify alkaline compositions prior to or during utilization.

\section{References}

[1] Qingke Nie, Wei Hu, Tao Ai et al. Strength properties of geopolymers derived from original and desulfurized red mud cured at ambient temperature. Construction and Building Materials 
2016; 125: 905-911.

[2] Wanchao Liu, Jiakuan Yang, Bo Xiao. Review on treatment and utilization of bauxite residues in China. International Journal of Mineral Processing 2009; 93(3-4): 220-231.

[3] Suchita Rai, Kailas L Wasewar, Jyoti Mukhopadhyay et al. Neutralization and utilization of red mud for its better waste management. Arch Environ Sci 2012; 6: 13-33.

[4] Xiaoming Liu, Na Zhang, Henghu Sun et al. Structural investigation relating to the cementitious activity of bauxite residue - Red mud. Cement \& Concrete Research 2011; 41(8): 847-853.

[5] Shengguo Xue, Feng Zhu, Xiangfeng Kong et al. A review of the characterization and revegetation of bauxite residues (Red mud). Environmental Science and Pollution Research International 2016; 23(2): 1120-1132.

[6] M.P. Rudraswamy, K.B. Prakash. An experimental investigation on the effect of alternation of alternate wetting and dry on the properties of concrete produced by red mud. International Journal of Adhesive Agricultural Research 2014; 2 (1): 473-484.

[7] Wanchao Liu, Xiangqing Chen, Wangxing Li et al. Environmental assessment, management and utilization of red mud in China. Journal of Cleaner Production. Journal of Cleaner Production 2014; 84: 606-610.

[8] Ran Zhang, Shili Zheng, Shuhua Ma et al. Recovery of alumina and alkali in Bayer red mud by the formation of andradite-grossular hydrogarnet in hydrothermal process. Journal of Hazardous Materials 2011; 189: 827-835.

[9] Li Zhong, Yifei Zhang, Yi Zhang. Extraction of alumina and sodium oxide from red mud by a mild hydro-chemical process. Journal of Hazardous Materials 2009; 172: 1629-1634.

[10] Chloe J Molineux, Darryl J Newport, Bamdad Ayati, et al., Bauxite residue (red mud) as a pulverised fuel ash substitute in the manufacture of lightweight aggregate. Journal of Cleaner Production 2016; 112: 401-408.

[11] Yingtang Xu, Bo Yang, Xiaoming Liu et al. Investigation of the medium calcium based non-burnt brick made by red mud and fly ash: durability and hydration characteristics. International Journal of Minerals, Metallurgy, and Materials 2019; 26: 983-991.

[12] Taoyong Liu, Xiuying Li, Liming Guan et al. Low-cost and environment-friendly ceramic foams made from lead-zinc mine tailings and red mud: Foaming mechanism, physical, mechanical and chemical properties. Ceramics International 2016; 42(1): 1733-1739.

[13] Vincenzo M. Sglavo, Stefano Maurina, Alexia Conci et al. Bauxite red mud in the ceramic industry. Part 2: Production of clay based ceramics. Journal of the European Ceramic Society 2000; 20(3): 245-252.

[14] Mansour Ghalehnovi, Naeim Roshan, Erfan Hakak et al. Effect of red mud (bauxite residue) as cement replacement on the properties of self-compacting concrete incorporating various fillers. Journal of Cleaner Production 2019; 240: 118213.

[15] Krivenko Pavel, Kovalchuk Oleksandr, Pasko Anton et al. Development of alkali activated 
cements and concrete mixture design with high volumes of red mud. Construction and Building Materials 2017; 151: 819-826.

[16] Jeffrey C Petermann, Athar Saeed. Alkali-Activated Geopolymers: A Literature Review, DTIC Document, 2010.

[17] Jian He, Yuxin Jie, Jianhong Zhang et al. Synthesis and characterization of red mud and rice husk ash-based geopolymer composites. Cemment and Concrete Composites 2013; 37: 108118.

[18] Anuj Kumar, Sanjay Kumar. Development of paving blocks from synergistic use of red mud and fly ash using geopolymerization. Construction and Building Materials 2013; 38: 865-871.

[19] Emile Mukiza, Xiaoming Liu, Lingling Zhang, Na Zhang. Preparation and characterization of a red mud-based road base material: Strength formation mechanism and leaching characteristics. Construction and Building Materials 2019; 220: 297-307.

[20] Lukmon Owolabi Afolabi, Zulkifli Mohamad Ariff and Puteri Sri Melor Megat-Yusoff et al. Redmud geopolymer composite encapsulated phase change material for thermal comfort in builtsector. Solar Energy 2019; 181: 464-474.

[21] Yanzhong Li, Changjun Liu, Zhaokun Luan et al. Phosphate removal from aqueous solutions using raw and activated red mud and fly ash. Journal of Hazardous Materials 2006; B137: 374383

[22] Ali Tor, Yunus Cengeloglu. Removal of congo red from aqueous solution by adsorption onto acid activated red mud. Journal of Hazardous Materials 2006; B138: 409-415.

[23] Ali Tor, Nadide Danaoglu, Gulsin Arslan, Yunus Cengeloglu. Removal of fluoride from water by using granular red mud: Batch and column studies. Journal of Hazardous Materials 2009; 164: 271-278.

[24] Yunus Cengeloglu, Ali Tor, Mustafa Ersoz et al. Removal of nitrate from aqueous phase by using red mud. Separation \& Purification Technology 2006; 51: 374-378.

[25] Güçlü Kubilay, Apak Reşat. Modeling of copper (II), cadmium (II), and lead (II) adsorption on red mud. Journal of Colloid and Interface Science 1998; 203: 122-130.

[26] Apak Reşat, Tütem Esma, Hügül Mehmet et al. Heavy metal cation retention by unconventional sorbents (red muds and fly ashes). Water Research 1997; 32: 430-440.

[27] Shiwen Bi. Technics of alumina production. Chemical industry press 2006, Beijing (in Chinese).

[28] MEC (Minerals Education Coalition) (2013) Alumina. Minerals education coalition. http://www.mineralseducationcoalition.org/minerals/ aluminum. Accessed 10 May 2015

[29] MII (Mineral Information Institute), 2009. Aluminum \& Bauxite. http://www.mii.org/Minerals/photoal.html.

[30] Xiaoming Li, Na Zhang. Utilization of red mud in cement production: a review. Waste Management and Research 2011; 29 (10): 1053-1063. 
[31] Liru Liu, Lu Aye, Zhongwu Lu, et al. Analysis of the overall energy intensity of alumina refinery process using unit process energy intensity and product ratio method. Energy 2006; 31 (8-9): 1167-1176.

[32] Sneha Samal, Ajoy K. Ray, Amitava Bandopadhyay. Proposal for resources, utilization and processes of red mud in India-A review. International Journal of Mineral Processing 2013; 118: 43-55.

[33] DI Smirnov, TV Molchanova. The investigation of sulphuric acid sorption recovery of scandium and uranium from the red mud of alumina production. Hydrometallurgy 1997; 45 (3): 249259.

[34] JE Kogel, NC Trivedi, JM Barker et al. 2006. Industrial minerals \& rocks, 7th ed. Society for Mining, Metallurgy, and Exploration, Littleton.

[35] FM Meyer.Availability of Bauxite reserves. Natural Resources Research 2004; 13 (3): 161-172.

[36] Zhongyu Yang. Alumina Production technology. Beijng, Metallurgical Industry Press 1993.

[37] Tingan Zhang, Wangxi Zhu. Technology of aluminum metallurgy. Science Press 2017, Beijing.

[38] Ekrem Kalkan. Utilization of red mud as a stabilization material for the preparation of clay liners. Engineering Geology 2006; 87(3-4): 220-229.

[39] Emile Mukiza, Lingling Zhang, Xiaoming Liu, Na Zhang. Utilization of red mud in road base and subgrade materials: A review. Resources, Conservation and Recycling 2019; 141: 187-199.

[40] C Klauber, M Gräfe, G Power. Bauxite residue issues: II. Options for residue utilization. Hydrometallurgy 2011; 108(1-2): 11-32.

[41] Faxiang Liu, Yuanyuan An, Shenggui Tang. Submerging test for dry stockpiling and consolidating red mud at the field. Science Technology and Engineering 2014; 27: 264-267.

[42] Yinghui Qiao. Technical study of mixed pond for red mud from Bayer process and red mud from sintering process. Light Metals 2004; (10), 18-20 (In Chinese).

[43] Pingping Rao. Analysis on basic characteristics of Bayer's dry red mud and the operation feature of the yard. Journal of Engineering Geology 2010; 18(3): 340-344.

[44] Ken Evans. The History, Challenges, and New Developments in the Management and Use of Bauxite Residue. Journal of Sustainable Metallurgy 2016; 2: 316-331.

[45] Guangjun Zhang. Quick opening pressure filter in dry red mud stockpiling. Automation Application 2014; 6: 35-36.

[46] R Bott, T Langeloh. Process options for the filtration and washing of bauxite residue. Bauxite Residue Valorization Conference 2015, Leuven, pp. 62-70.

[47] Shengguo Xue, Xiangfeng Kong, Feng Zhu et al. Proposal for management and alkalinity transformation of bauxite residue in China. Environmental Science and Pollution Research 2016; 2312822-12834.

[48] RK Paramguru, PC Rath, VN Misra. Trends in red mud utilization - a review. Mineral Processing 
and Extractive Metallurgy Review 2006; 26, 1-29.

[49] World Aluminium and the European Aluminium Association "Bauxite Residue Management: Best Practice", available from the International Aluminium Institute, 10 King Charles II Street, London, SW1Y 4AA, UK and on line from http://bauxite.worldaluminium. org/refining/bauxite-residue-management.html

[50] Zigao Liu, Changshi Yang, Zonghao Cheng et al. Treatment and utilization of redmud derivedfrom Bayer process. The Chinese Journal of Nonferrous Metals 1997; 7, 40-44 (In Chinese).

[51] Hualei Zhou, Dongyan Li, Yajun Tian et al. Extraction of scandium from red mud by modified activated carbon and kinetics study. Rare Materials 2008; 27: 223-227.

[52] Feng Gao, Jihao Zhang, Xinjie Deng et al. Comprehensive Recovery of Iron and Aluminum from Ordinary Bayer Red Mud by Reductive Sintering-Magnetic Separation-Digesting Process. 2019 The Minerals, Metals \& Materials Society.

[53] Juanjuan Zhang. Preliminary study recovery titanium dioxide from red mud of industrial slag. China Resource Comprehensive Utilization 2003; (1): 28-30 (In Chinese).

[54] Claudia Brunori, Carlo Cremisini, Paolo Massanisso, et al. Reuse of a treated red mud bauxite waste: studies on environmental compatibility. Journal of Hazardous Materials 2005; 117 (1): 55-63.

[55] Chunlei Zhu, Zhaokun Luan, Yanqiu Wang, et al. Removal of cadmium from aqueous solutions by adsorption on granular red mud (GRM). Separation and Purification Technology 2007; 57 (1): 161-169.

[56] Shuwu Zhang, Changjun Liu, Zhaokun Luan, et al. Arsenate removal from aqueous solutions using modified red mud. Journal of Hazardous Materials 2008; 152: 486-492.

[57] Yi Chen, Junqi Li, Fang Huang, et al. The performance research on absorbing $\mathrm{SO}_{2}$ waste gas with Bayer red mud. Journal of Guizhou University of Technology (Natural Science Edition) 2007; 36 (4): 30-32. (In Chinese).

[58] Giovanni Garau, Paola Castaldi, Laura Santona, et al. Influence of red mud, zeolite and lime on heavy metal immobilization, culturable heterotrophic microbial populations and enzyme activities in a contaminated soil. Geoderma 2007; 142 (1-2): 47-57.

[59] P.E. Tsakiridis, S. Agatzini-Leonardou, P. Oustadakis. Red mud addition in the raw meal for the production of Portland cement clinker. Journal of Hazardous Materials B116 (2004) 103-110.

[60] Jiakuan Yang, Dudu Zhang, Jian Hou et al. Preparation of glass-ceramics from red mud in the aluminium industries. Ceramics International 2008; 34: 125-130.

[61] Xiaofeng Wang, Haiyan Lin, Yongfu Yang et al. Preparation of burned brick by red mud of Bayer process. New Building Materials 2007; 34 (7): 24-26 (In Chinese).

[62] Xiaorang Tian, Bolin Wu, Jian Li. The exploration of making acidproof fracturing proppants using red mud. Journal of Hazardous Materials 2008; 160 (2-3): 589-593.

[63] Yang, J.K., Liu, W.C., Li, G., et al. A kind of composite brick made from red mud in Bayer process and its production method. China Patent 2008, No. 200810046629.4.

[64] Achal Garg, Harindar Yadav. Study of red mud as an alternative building material for interlocking block manufacturing in construction industry. International Journal of Materials Science and Engineering 2015; 3: 295-300. 
[65] Harekrushna Sutar. Progress of red mud utilization: an overview. American Chemical Science Journal 2014; 4: 255-279.

[66] K Deelwal, K Dharavath, M Kulshreshtha. Evaluation of characteristic properties of red mud for possible use as a geotechnical material in civil construction. International Journal of Advanced Engineering Technology 2014; 7: 1053-1059.

[67] Chuansheng $\mathrm{Wu}$, Dongyan Liu. Mineral phase and physical properties of red mud calcined at different temperatures. Journal of Nanomaterials 2012; doi.org/10.1155/2012/628592.

[68] PM Prasad, M Singh. Problems in the disposal and utilization of red muds. The Banaras Metallurgist 1997; 14 \&15: 127-140.

[69] Jizhe Zhang, Shengjie Liu, Zhanyong Yao et al., Environmental aspects and pavement properties of red mud waste as the replacement of mineral filler in asphalt mixture. Construction and Building Materials 2018; 180: 605-613.

[70] Yuehua Jiang, Yong Liu, Chuxia Lin. Chemistry and mineralogy of red mud and its utilization in Zhengzhou Alumina Refinery. Light Metals 2007; 10: 18-21 (in Chinese).

[71] Xiangli Nan, Tingan Zhang, Yan Liu et al. The main categories of red mud and its influence on the environment in China. Chinese Journal of Process Engineering 2009; S1: 459-464 (in Chinese).

[72] L Pérez-Villarejo, FA Corpas-Iglesias, S Martínez-Martínez et al. Manufacturing new ceramic materials from clay and red mud derived from the aluminium industry. Construction and Building Materials 2012; 35: 656-665.

[73] Edemarino Araujo Hildebrando, José Antônio da Silva Souza, Rômulo Simões Angélica, Roberto de Freitas Neves. Application of Bauxite Waste from Amazon Region in the Heavy Clay Industry. Materials Research. 2013; 16(6): 1418-1422.

[74] Sneha Samal, Ajoy K. Ray, Amitava Bandopadhyay. Characterization and microstructure observation of sintered red mudefly ash mixtures at various elevated temperature. Journal of Cleaner Production 2015; 101: 368-376.

[75] Srinivasan Srikanth, Ajay Kumar Ray, Amitava Bandopadhyay, Bandari Ravikumar. Phase Constitution During Sintering of Red Mud and Red Mud-Fly Ash Mixtures. Journal of the American Ceramic Society 2005; 88(9): 2396-2401.

[76] Suchita Rai, KL Wasewar and A Agnihotri. Treatment of alumina refinery waste (red mud) through neutralization techniques: A review. Waste Management \& Research 2017; 35(6): 563-580.

[77] Ping Wang, Dongyan Liu. Physical and Chemical Properties of Sintering Red Mud and Bayer Red Mud and the Implications for Beneficial Utilization. Materials 2012; 5: 1800-1810.

[78] Jizhe Zhang, Peizhao Li, Ming Liang et al. Utilization of red mud as an alternative mineral filler in asphalt mastics to replace natural limestone powder. Construction and Building Materials 2020; 237: 117821. 
[79] Suk-Pyo Kang, Seung-Jun Kwon. Effects of red mud and Alkali-Activated Slag Cement on efflorescence in cement mortar. Construction and Building Materials 2017; 133: 459-467.

[80] Jian He, Jianhong Zhang, Yuzhen Yu et al. The strength and microstructure of two geopolymers derived from metakaolin and red mud-fly ash admixture: A comparative study. Construction and Building Materials 2012; 30: 80-91.

[81] Sneha Samal, Ajoy K. Ray, Amitava Bandopadhyay. Characterization and microstructure observation of sintered red mud-fly ash mixtures at various elevated temperature. Journal of Cleaner Production 2015; 101: 368-376

[82] Xiangfeng Kong, Meng Li, Shengguo Xue et al. Acid transformation of bauxite residue: Conversion of its alkaline characteristics. Journal of Hazardous Materials 2017; 324: 382-390.

[83] Sahu Ramesh Chandra, Patel, Raj Kishore,Ray, Bankim Chandra. Neutralization of red mud using $\mathrm{CO}_{2}$ sequestration cycle. Journal of Hazardous Materials 2010; 179: 28-34.

[84] Ruyters Stefan, Mertens Jelle, Vassilieva Elvira et al. The red mud accident in Ajka (Hungary): plant toxicity and trace metal bioavailability in red mud contaminated soil. Environmental Science \& Technology 2011; 45: 1616-1622.

[85] Government of Hungary, 2010. Red Sludge and Detoxification. http://redsludge.bm.hu/?p=59\#more-59.).

[86] Loretta Y Li. Properties of red mud tailings produced under varying process conditions. Journal of Environmental Engineering 1998; 124(3): 254-264.

[87] Attila Anton, Márk Rékási, Nikolett Uzinger, et al., Modelling the potential effects of the Hungarian red mud disaster on soil properties. Water, Air, \& Soil Pollution 2012; 223: 51755188.

[88] Jingang Wang. Characterization of Failure and Permanent Deformation Behaviour of Asphalt Concrete. PhD Dissertation. Delft University of Technology. 2015.

[89] Dongxing Xuan, André A. A Molenaar, Lambert J. M Houben. Compressive and indirect tensile strengths of cement treated mix granulates with recycled masonry and concrete aggregates. Journal of Materials in Civil Engineering 2012; 24(5): 577-585.

[90] Aimin Sha. Material characteristics of a semi-rigid base. China Journal of Highway and Transport 2008; 21(1): 1-5.

[91] Shengli Li, Guangming Wu, Hao Wu. Study on acoustic emission characteristics of a semirigid base of dense skeleton type during complete uniaxial compression tests. Advances in Materials Science and Engineering 2016; DOI 10.1155/2016/9238698.

[92] Dongxing Xuan, Lambert J. M Houben, André A. A Molenaar, Zhonghe Shui. Mechanical properties of cement-treated aggregate material - A review. Materials \& Design 2012; 33(1): 496-502.

[93] Shutang Liu, Zhuozhi Li, Yingyong Li, Weidong Cao. Strength properties of Bayer red mud stabilized by lime-fly ash using orthogonal experiments. Construction and Building Materials 
2018; 166: 554-563.

[94] The Ministry of Communications of the People's Republic of China, Technical Guidelines for Construction of Highway Roadbases, JTG/T F20-2015, China Communication Press, Beijing, 2015.).

[95] SM Farooq, MA Rouf, SMA Hoque et al. Effect of lime and curing period on unconfined compressive strength of Gazipur soil. 4th Annual Paper Meet and 1st Civil Engineering Congress. Bangladesh 2011; pp. 4-8.

[96] Yuliang Zhang, Xiaoming Liu, Yingtang Xu et al., Synergic effects of electrolytic manganese residue-red mud-carbide slag on the road base strength and durability properties. Construction and Building Materials 2019; 220: 364-374.

[97] Wei Hu, Qingke Nie, Baoshan Huang et al. Mechanical property and microstructure characteristics of geopolymer stabilized aggregate base. Construction and Building Materials 2018; 191: 1120-1127.

[98] Nan Yea, Ye Chen, Jiakuan Yang et al. Co-disposal of MSWI fly ash and Bayer red mud using an one-part geopolymeric system. Journal of Hazardous Materials 2016; 318: 70-78.

[99] J. Davidovits. Geopolymers - inorganic polymeric new materials. Journal of Thermal Analysis 1991; 37: 1633-1656.

[100] General administration of quality supervision, Inspection and Quarantine of the People's Republic of China, Limits of radionuclides in building materials (in Chinese), 2010.

[101] National Environmental Protection Administration, Solid waste-Extraction procedure for leaching toxicity- Acetic acid buffer solution method (In Chinese), 2007.

[102] D. Movilla-Quesada, A.C. Raposeiras, D. Castro-Fresno, D. Peña-Mansilla, Experimental study on stiffness development of asphalt mixture containing cement and $\mathrm{Ca}(\mathrm{OH})_{2}$ as contribution filler. Materials and Design 2015; 74: 157-163.

[103] Chao Li, Zongwu Chen, Shaopeng Wu et al. Effects of steel slag fillers on the rheological properties of asphalt mastic. Construction and Building Materials 2017; 145: 383-391.

[104] V. Antunes, A.C. Freire, L. Quaresma, R. Micaelo. Influence of the geometrical and physical properties of filler in the filler-bitumen interaction. Construction and Building Materials 2015; 76: 322-329.

[105] Peiqiang Cui, Shaopeng Wu, Yue Xiao et al. Inhibiting effect of Layered Double Hydroxides on the emissions of volatile organic compounds from bituminous materials. Journal of Cleaner Production 2015; 108: 987-991.

[106] Gordon Airey, Minchi Liao, Nick Thom. Fatigue Behaviour of Bitumen-Filler Mastics. 10th International Conference on Asphalt Pavements. Quebec city, Canada, 2006.

[107] HU Bahia, A Faheem, C Hintz et al. Test Methods and Specification Criteria for Mineral Filler Used in HMA, Transportation Research Board, USA, 2010.

[108] Tao Fu, Hui-ming Bao and Xingxing Duan. Molecular Simulation Study on Modification 
Mechanism of Red Mud Modified Asphalt. 1st International Global on Renewable Energy and Development (IGRED 2017).

[109] Hengji Zhang, Hui Li, Ahmed Abdelhady et al. Optimum Filler-Bitumen Ratio of Asphalt Mortar Considering Self-Healing Property. Journal of Materials in Civil Engineering 2019; 31(8): 04019166

[110] Hengji Zhang, Hui Li, Ahmed Abdelhady et al. Utilization of Fine Solid Waste in Asphalt Mortar. Journal of Testing and Evaluation; https://doi.org/10.1520/ JTE20180636

[111] Jizhe Zhang, Changjun Sun, Peizhao Li et al. Experimental study on rheological properties and moisture susceptibility of asphalt mastic containing red mud waste as a filler substitute. Construction and Building Materials 2019; 211: 159-166.

[112] Hengji Zhang, Hui Li, Yi Zhang et al. Performance enhancement of porous asphalt pavement using red mud as alternative filler. Construction and Building Materials 2018; 160: 707-713.

[113] Jizhe Zhang, Alex K. Apeagyei, Gordon D. Airey et al. Influence of aggregate mineralogical composition on water resistance of aggregate-bitumen adhesion. International Journal of Adhesion \& Adhesives 2015; 62: 45-54.

[114] Jayvant Choudhary, Brind Kumar, Ankit Gupta. Application of waste materials as fillers in bituminous mixes. Waste Management 2018; 78: 417-425.

[115] Rajan Choudhary, Abhinay Kumar, Ghazali Rahman. Rheological and mechanical properties of bauxite residue as hot mix asphalt filler. International Journal of Pavement Research and Technology 2019; 12: 623-631.

[116] Jayvant Choudhary, Brind Kumar, Ankit Gupta. Performance evaluation of bauxite residue modified asphalt concrete mixes. European Journal of Environmental and Civil Engineering, DOI: 10.1080/19648189.2019.1691662

[117] Mayara Siverio Lima, Liseane P. Thives, Viktors Haritonovs. Rutting performance of bituminous mixtures composed with red mud. The 10th International Conference on the Bearing Capacity of Roads, Railways and Airfields (BCRRA 2017)

[118] Amir Modarres, Alinia Bengar Paymen. Investigating the indirect tensile stiffness, toughness and fatigue life of hot mix asphalt containing copper slag powder. International Journal of Pavement Engineering 2019; 20(8): 977-985.

[119] ASTM D1075-11. (2007). Standard test method for effects of water on compressive strength of compacted bituminous mixtures. West Conshohocken, PA: American Society for Testing and Materials.

[120] MORTH (Ministry of Road Transport \& Highways). (2013). Specifications for road and bridge works, Section 500, Fifth Revision. New Delhi: Indian Roads Congress. 